\title{
Analysis of Slope Sensitivity to Landslides by a Transdisciplinary Approach in the Framework of Future Development: The Case of La Trinité in Martinique (French West Indies)
}

\author{
Yannick Thiery ${ }^{1, *}$ (D) , Pierre-Alexandre Reninger ${ }^{2}$, Frederic Lacquement ${ }^{2}$, Anne Raingeard ${ }^{2}$, \\ Maeva Lombard ${ }^{3}$ and Aude Nachbaur ${ }^{3}$ \\ 1 French Geological Survey, Risk and Prevention Division, 45100 Orléans, France \\ 2 French Geological Survey, GeoRessources Division, 45100 Orléans, France; pa.reninger@brgm.fr (P.-A.R.); \\ f.lacquement@brgm.fr (F.L.); a.raingeard@brgm.fr (A.R.) \\ 3 French Geological Survey, Regional Division, 97200 Martinique, France; m.lombard@brgm.fr (M.L.); \\ a.nachbaur@brgm.fr (A.N.) \\ * Correspondence: y.thiery@brgm.fr; Tel.: +33-2-3864-4831
}

Received: 19 November 2017; Accepted: 14 December 2017; Published: 19 December 2017

\begin{abstract}
Landslide hazard and risk assessment (LHA \& LRA) in the French West Indies is a big challenge, particularly in Martinique, where several factors contribute to high slope sensitivity to landslides. This sensitivity is particularly due to volcanic ground, hurricane seasons, and growing pressure from urban development. Thus, to protect future goods and inhabitants and avoid increased slope sensitivity to landslide, it is necessary to analyze by different ways and complementary approaches the future planned areas. This research focuses on a site the City Council of 'La Trinité' wishes to develop. The goals consist of locating landslide-prone areas and providing some recommendations/indications for future projects. The site is characterized by a hilly topography alternating steep slopes, gentle slopes, and eroded areas and is located on a complex lithology (i.e., andesite, basalt, and weathered materials). By combining several approaches and techniques (geology, geomorphology, geophysics, and modeling), it is demonstrated that some areas are particularly susceptible to landslide, notably where colluviums are juxtaposed to highly weathered materials. The different documents produced, based on modeling and expert knowledge, combined with indications should allow the definition of new susceptibility classes, taking into account probable anthropic influence and development. Even if the temporal probability of the experimental documents is not taken into account, they help with refining knowledge of landslide-prone areas and different types of instability. The documents should be discussed with end users for future planning.
\end{abstract}

Keywords: landslide; hazard; risk; development; anthropic influence; TDEM; 3D geological models

\section{Introduction}

The West Indies are regularly the site of various natural hazards (e.g., hurricanes, earthquakes, floods, and, more rarely, tsunamis). Between 1990 and 2008 this part of the globe was affected by 165 natural disasters with high impact. The total impact (damage and losses) for this period was estimated to be $\$ 136$ billion, with the economic impact estimated at $\$ 63$ billion (46\% [1]).

Among these natural hazards, landslides generate some damage, paralyzing populations, economic activities, and administrations [2]. Gradually, these countries began to feel the need to equip themselves with decision-making tools, hazard maps, and crisis management tools in order to (1) improve spatial planning and infrastructure development of their territory and (2) give recommendations and operational answers in case of crisis. Therefore, they have collaborated with 
aid agencies or major global organizations to provide prevention and mitigation means: e.g., in 2012 the World Bank, in partnership with the ACP-EU Natural Disaster Reduction Program, initiated the Caribbean Risk Information Program [3-7]. The project focused on (1) landslide and flood hazard information in order to apply all the collected information to future planning and infrastructure development and (2) improving the management strategies of the countries involved (i.e., Dominica, Saint Lucia, Saint Vincent and the Grenadines, Grenada, and Belize).

The French West Indies are not spared by landslide phenomena. Often generated by hurricanes or tropical storms, these processes regularly strike the coasts and the hinterlands. For instance, in Guadeloupe in 1995, following the 'Luis' and 'Maryline' hurricanes, landslides caused the closure of the Road RD 23 ('Route des Mamelles') for three months, generating non-negligible socioeconomic impacts [8]. For this island, the sums of money devoted to the road rehabilitation amounted to several thousands of euros (e.g., in 1989, €5 million was spent after Hurricane 'Hugo'). Martinique Island was hit by the Bellefontaine collapse, which required $€ 7$ millions of work to rehabilitate the slope after the event. More recently, in 2011 in Morne Callebasse (Fort-de-France), a landslide followed by a flow (volume about $200,000 \mathrm{~m}^{3}$ and $10,000 \mathrm{~m}^{3}$, respectively; [9]) destroyed more than 20 buildings and the road 'RD 48', and 75 expulsions were ordered. The total cost of the works was estimated at $€ 17.1$ million [9]. These disorders may be of natural origin, but in many cases landslides affect slopes of cuttings, embankments, or slopes that are not managed and poorly drained, leading to an increase in their occurrence probability. They result from the presence of anthropogenic development that did not take into account the landslide susceptibility [10-12]).

If the French West Indies are subject to the same rules as the metropolis territory in terms of territorial planning with risk prevention plans (PPR-Plans de Prévention des Risques, taking into account the predisposition and triggering factors of natural processes, [12]), it seems difficult to apply the rules efficiently as the land pressure is strong (density about 355 inh. $\mathrm{km}^{-2}$; either the 11th French department). Thus, some municipalities are trying to plan development for previously abandoned agricultural sectors or forests considered to be in the moderate hazard and/or risk class. Areas considered to be in the moderate hazard class are subject to specific management rules and require a better knowledge of the inherent parameters of slopes, soil, and subsoil and about aggravating factors like anthropogenic activity [10-14]. Thus, to avoid an increase in the sensitivity of slopes to instability and to protect future goods and inhabitants, it is necessary to analyze by different ways and complementary approaches the future planned areas [11,13,15].

Several approaches can be used, ranging from a simple approach based on an inventory and expert map and needing few data, to more complex approaches based on discrete and/or continuum-based models needing a large amount of data $[11,13,16]$. Practitioners prefer to obtain more accurate analyses and can be attracted by sophisticated studies. However, answering such a demand may be long, costly, and cumbersome to put in place. Indeed, it is essential to proceed step by step with geotechnical studies, relying on drilling, laboratory tests on materials to derive geotechnical values, analysis of triggering factors, and then modeling [11-16]. Another solution consists of using proven geophysical techniques and investigations (geo-electrical or seismic tomography) to provide information on the internal geometry and structure of a regolith [17-24]. Coupled with field investigations and ground penetration, it is possible to define the internal layering and possible shear surfaces [23-26]. In this way, an expert is able to find some adapted solutions (stabilization, earthwork, reinforcement, drainage, etc.) by creating different situations with the introduction of different forcing factors (e.g., Peak Ground Acceleration-PGA; Ground Water Level-GWL). The more tests there are, the more complete the study will be, and when the site is spatially restricted, costs can be reduced.

In the case of development projects in complex environments, such as the French West Indies, which present superimposed healthy and weathered lavas, it is difficult to carry out such studies. It is indispensable to multiply the tests in order to reduce the environmental uncertainty. Moreover, with the aim of cost reduction while obtaining reliable results, it is necessary to find technical means in order to target sites that will be the subject of further geotechnical studies [27]. One possible 
solution consists of obtaining some information by the use of remote sensing techniques, especially airborne geophysics [28-31]. Compared to others remote sensing technique, airborne geophysics is able to provide plentiful information about several tens of meters depth in a short period time for large areas [29-31]. If the use of this method seems expensive, the multiplicity of sensors used in parallel allows for a reduction in costs by comparison with the same investigations on the ground. In Martinique, such a survey has been available since 2013 [32,33]. The main goal was to collect new information about the rocks (geology, lithology) and reveal the subsoil (regolith, hydrogeology) up to $200 \mathrm{~m}$ depth using the Time Domain Electromagnetic Method (TDEM). Recently, as requested by the Hazard and Risk Department of the Environmental and Ecological Ministry, some technical studies [34-37] on shallow and deep landslides based on TDEM-derived data and spatial modeling have demonstrated the full potential of a coupled approach to assess landslide-prone areas.

Thus, when the municipality of 'La Trinité', located on the east coast of Martinique, wished to develop an area untouched by any development but located in a moderate susceptibility/hazard class, it was necessary to understand what conditions the potential instabilities might provoke. Indeed, understanding the soil and slope processes according to local triggering conditions is an essential pre-requisite before proceeding to further studies of land stability $[11,15]$. In our case, the use of new data, acquired during the geophysical helicopter campaign, will provide additional information about the type and thickness of soil and subsoil, which are often missing for this type of study. Thereby, the overall objectives are: (1) to define weathered horizons of lavas by field observations; (2) to obtain the internal structure of the regolith with the help of TDEM data; (3) to assess the stability of slopes by elaboration of scenarios based on physically based models tested for the same environment near the study site; and (4) to identify the most landslide-prone areas and give some recommendations to the municipality.

\section{Study Site and Landslides}

\subsection{Study Site}

The study site is located in the municipality of La Trinité, Martinique (Figure 1). La Trinité is affected by natural hazards, particularly slope instabilities, with 17 landslides and nine mudflows inventoried and included in the French landslide database (BDMVT). The site belongs to the unit of the Vauclin-Pitault submarine volcanic chain (Miocene, [38]; Figure 2). This unit is represented by the Vert-Pré porphyric basalt lava flows (14.8 to $14 \mathrm{My}$; Figure 2) and the more recent dark porphyric andesite lava flows (2.8 to 2.2 My; Figure 2).

The area, subject to future development by end-users, is located to the north of the municipality (Figure 1B). This area, with a surface of about $1 \mathrm{~km}^{2}$ (Figures 1 and 2), is limited in the south by crests carved in recent andesite lava flow formations and dominated by the Morne Congo $(266 \mathrm{~m}$ a.s.l.). Under the crests, the topography is very steep $\left(>30^{\circ}\right)$, with gullies and alternation of steep to very steep slopes like in Bonneville. Paradoxically, these slopes are well developed but can be affected by landslides, as happened in 2009 ([38]; Figure 3). Below the steep slopes (the Bocage and Merveilleuse neighborhoods), the morphology is hilly, alternating steep convex slopes $\left(>25^{\circ}\right)$ with planar and concave slopes $\left(<20^{\circ}\right)$. This lower area is incised by gullies, which give a glimpse of the lithology when the incision is strong. The area is mostly rural and covered by farming parcels (banana, vegetable, and other fruit plantations), with few inhabited. The National Road $n^{\circ} 1$ (RN1) marks the northern boundary of the site. 

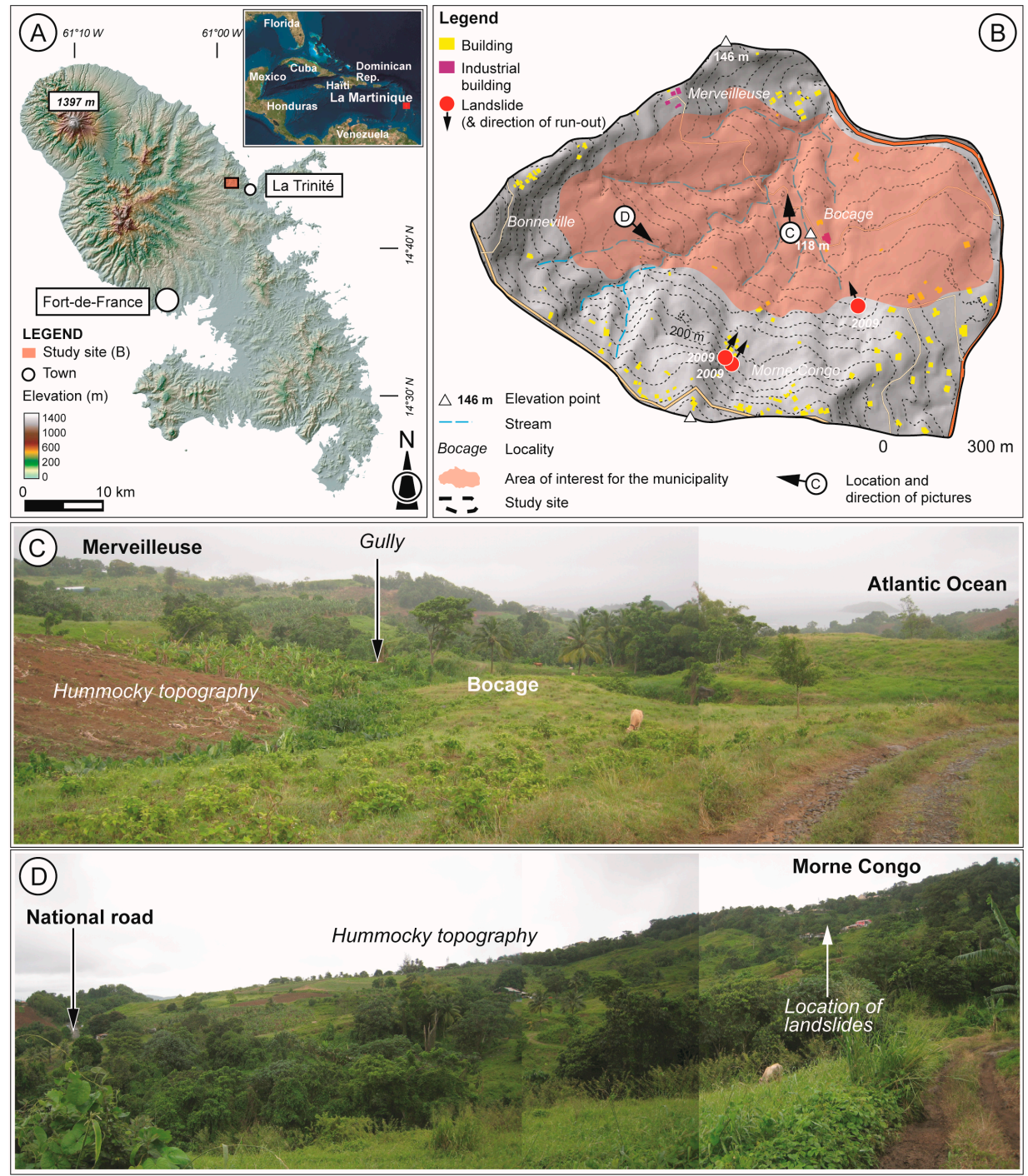

Figure 1. Location of the test site (coordinates are expressed in Lat/Long; projection WGS84 UTM 20N-EPSG 32620). (A) Location of Martinique and test site; (B) study area; (C) view of Merveilleuse from the track; (D) view of Morne Congo from Bonneville.

\subsection{Landslides}

Three landslides were observed in 2009 (Figure 1B), after a tropical storm [39]. These shallow phenomena (debris-slide; Figure 3A) affected unconsolidated materials such as colluviums or weathered materials [40-42]. The involved materials had evolved into flows in the downhill slope. The length of the phenomenon is a maximum of $70 \mathrm{~m}$ for a maximum width of $20 \mathrm{~m}$. Because the morphological features completely disappeared (restoration works) and are covered by vegetation, it is currently difficult to observe them. These landslides destroyed two property walls, invaded a part of the ground floor of a house, and destroyed a shelter (Figure 3A,B).

Near the study area, one active, deep landslide (Morne-Figue landslide, Figure 3B) was investigated in 1989 [43] and has benefited from technical studies in 2015 and 2016 [35-37]. The length of the failure area is $80 \mathrm{~m}$ and about 80 for the run-out area, for a maximum width of $160 \mathrm{~m}$. In 2004, the reactivation of this rotational landslide $[42,44]$ induced new road failures and the subsidence of a part of a workshop (Figure 3C-E). Currently, the road is locally repaired (Figure 3E). The geomorphological features of this near area correspond more or less to the morphology of the upper part of the study 
site, with the thickness of weathered materials and colluviums ranging from about $2 \mathrm{~m}$ to $10 \mathrm{~m}$ and covering basalt lava flows.

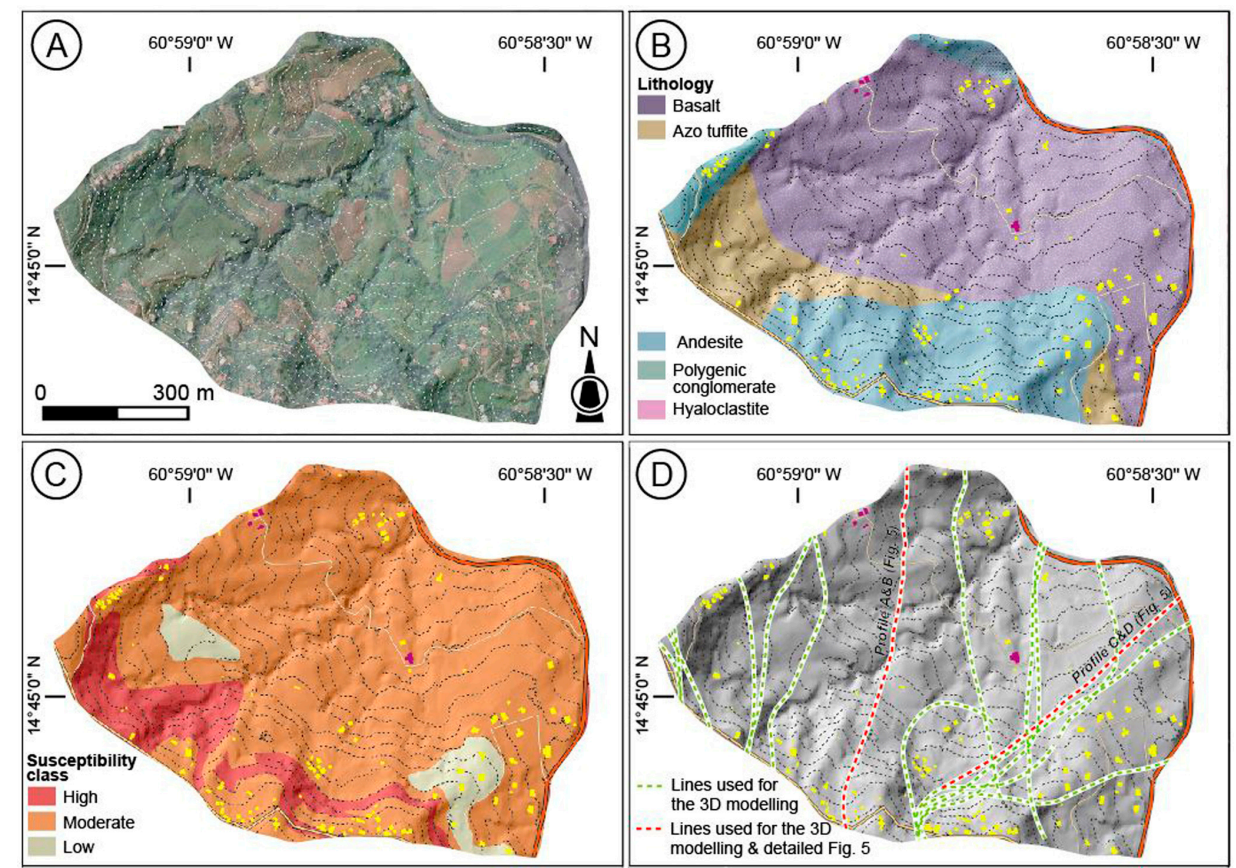

Figure 2. (A) Aerial photograph of the site (BD Ortho ${ }^{\circledR}$, IGN 2010) and geomorphological interpretations; (B) geological map made at 1:50,000 scale of work [45]; (C) official landslide susceptibility/hazard map (PPR); (D) locations of helicopter flight lines used for this research. (Coordinates are expressed in Lat/Long; projection WGS84 UTM 20N_EPSG 32620.)
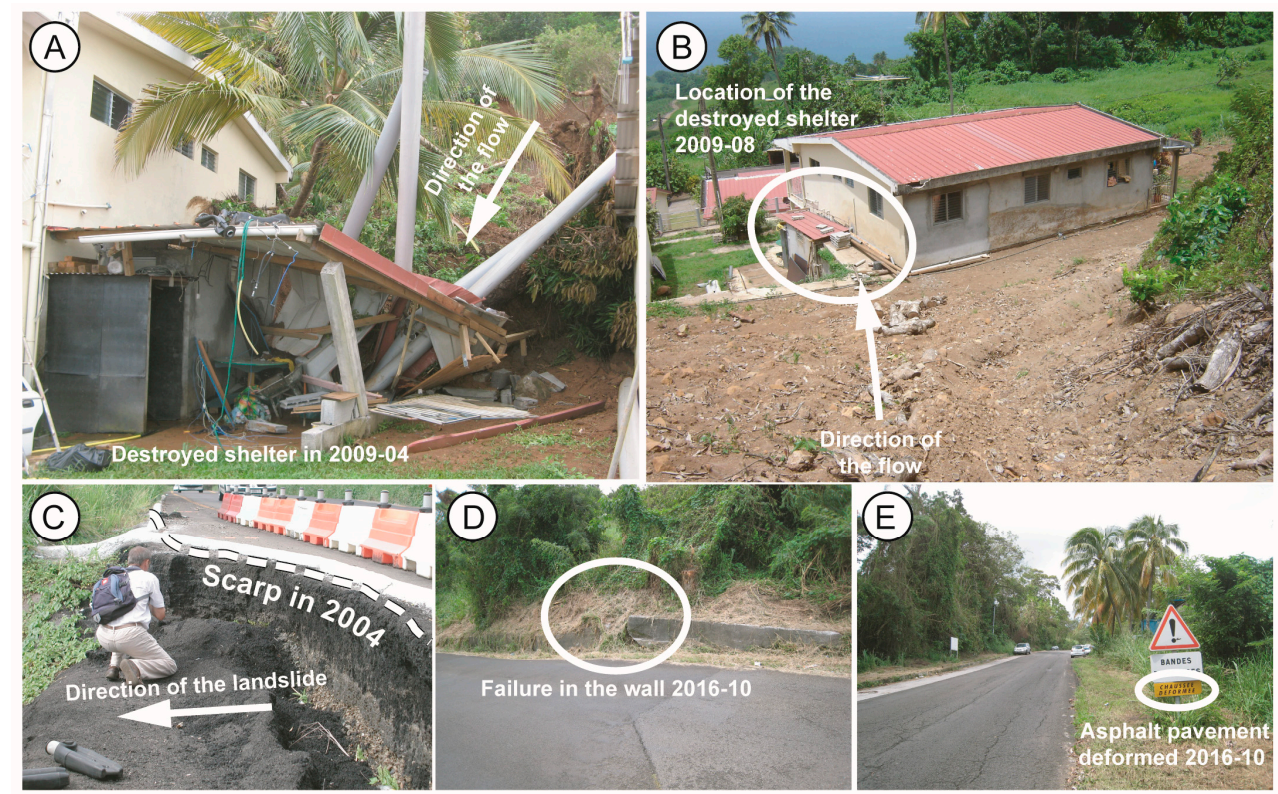

Figure 3. (A) Shallow landslide in Morne Congo occurring in April 2009; (B) slope of the shallow landslide (Figure 3A) after works in August 2009; (C) Morne-Figue landslide in 2004 after reactivation of the upper part; (D) failure in a wall downstream of the Morne-Figue landslide (2016); (E) municipality road deformed by the Morne-Figue landslide (2016). 


\section{Methods and Materials}

The employed methodology was based on a transdisciplinary approach in order to reduce the uncertainties due to the lack of knowledge about landslide initiation in the Merveilleuse and Bocage neighborhoods (Figure 1B). Six interconnected steps were defined (Figure 4): (1) the production of a regolith map, taking into account the different surficial formations and the weathering degree of different materials; (2) the production of a 3D geological model, taking into account the regolith and the depth lithology; ( 3 \& 4) landslide susceptibility analysis with implementation of a deterministic model based on the Limit Equilibrium Model with tests of different scenarios (different ground water levels and with slope planning); (5) based on steps 3 and 4, elaboration of landslide susceptibility map with a spatially physically based approach modeling failure areas and a cellular automata computing run-out envelope; and (6) recommendations/indications according to the new results.

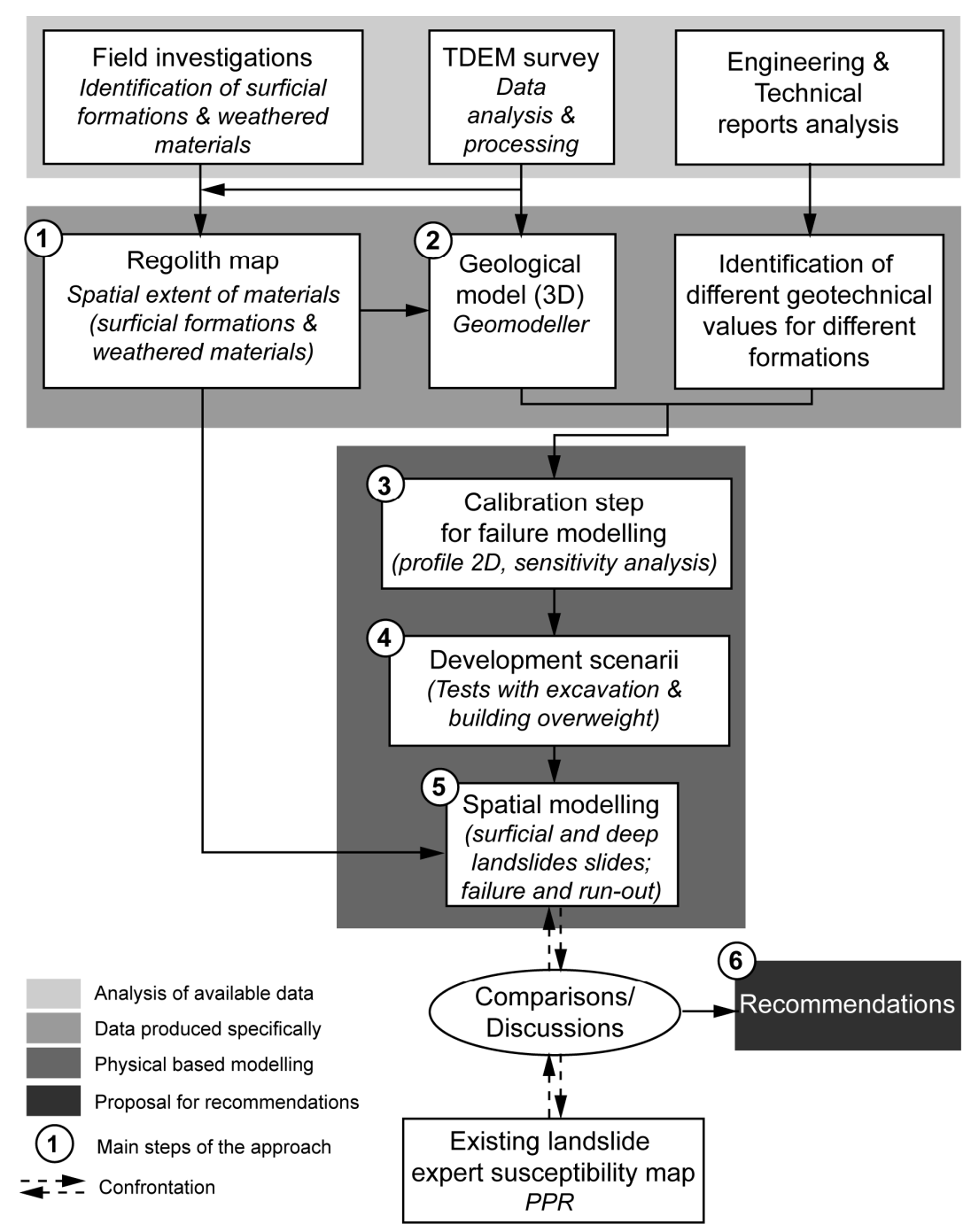

Figure 4. General methodology flow chart.

\subsection{Identification of Regolith (Surficial and Weathered Materials)}

The surficial formations resulting from rock weathering are one of the main landslide predisposing factors in French West Indies $[43,45,46]$. Little spatial information was available about lava types and only the geological map produced by [45], at 1:50,000 scale, gave an overview of large lithological sets. Nevertheless, the document is not adapted to our work because (1) there were several lithological 
variations within large ensembles and (2) the weathering degree of the lithology was not mentioned. Therefore, a detailed regolith map presenting the different lava types, weathering degree, and surficial formations was carried out at 1:10,000 scale. Based on field observations, the work consisted of characterizing the different outcrops in terms of:

1. The nature and implementation of the formations, allowing one to differentiate between the formations associated with different volcanic edifices (andesitic and basaltic flows, tuffs) and the formations associated with their dismantling and associated implementation process (colluvium, alluvium);

2. The degree of weathering for each observed lithology. The weathering degree is assessed by the intensity of the fracturing in the rocks associated with the supergene phenomena and the degree of rock modification from a healthy stage without cracks to disaggregating rock into saprolite and alloterite [46-48]. The outcrops are listed in a typical weathering profile and belong to one of the following five types of horizons given in Figure 5.

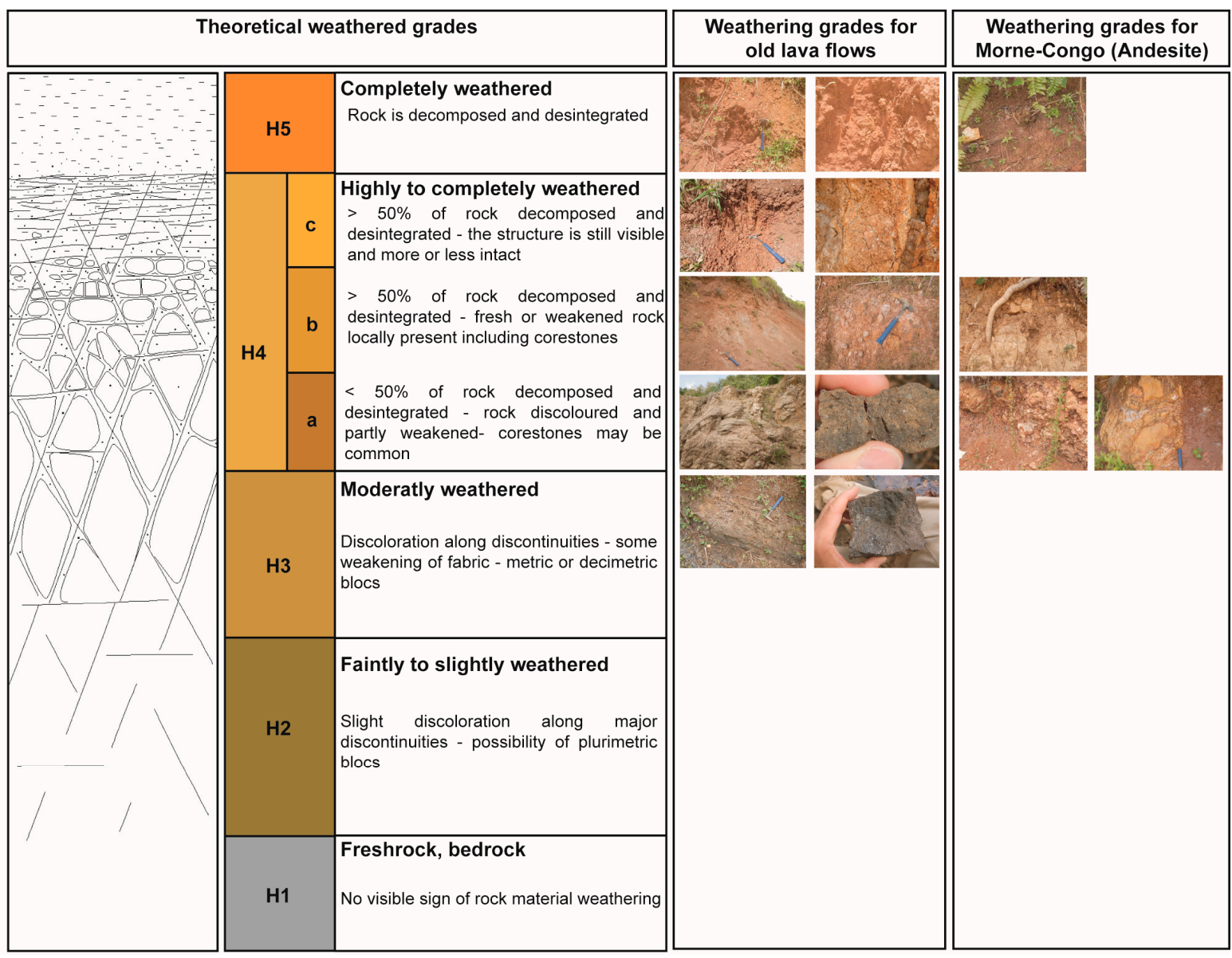

Figure 5. Weathered grades used (adapted from [48,49]).

This fieldwork was completed by the analysis of topography, aerial photograph interpretation, and information derived from the helicopter-borne TDEM survey. This type of geophysical analysis made it possible to correlate TDEM to certain outcrops and to spatialize areas where the accessibility did not allow for making relevant observations. The description of the dispositive is given in the next section. 


\subsection{TDEM and 3D Geological Model}

\subsubsection{Background}

From 29 January to 16 March 2013, a helicopter-borne TDEM survey was conducted by SkyTEM ApS [50] over the whole of Martinique Island. This survey, supervised by BRGM (French Geological Survey, Orléans, France) for geological and hydrogeological purposes, was flown mainly along the $\mathrm{N}-\mathrm{S}$ direction (some parts were flown in other directions according to the topography) with a 400-m framework, locally refined with a line spacing of 200 to $100 \mathrm{~m}$, for a total of 3730 line kilometers. The spacing between each EM sounding along flight lines is approximately $30 \mathrm{~m}$ and the nominal height of the loop was on average about $64 \mathrm{~m}$ due to the sharp topography of the island.

\subsubsection{Technical Dispositive}

The SkyTEM is a helicopter-borne TDEM system [50] developed by the Hydro Geophysics Group of Aarhus (Denmark) for hydro-environmental investigations. This system is composed of (1) a transmitter coil, exciting the subsurface; (2) a receiver coil, to measure the ground response; (3) a generator, as a power source; and (4) several navigation instruments such as GPS, tiltmeters, and laser altimeters in order to locate at each moment the loop in the space. The SkyTEM system operates in a dual transmitter mode. The low moment, with a magnetic moment of approximately $2826 \mathrm{Am}^{2}$ and time gates from $11 \mu \mathrm{s}$ to $1 \mathrm{~ms}$ for the present survey, provides early time data for shallow imaging and the high moment, with a magnetic moment reaching 144,440 $\mathrm{Am}^{2}$ and time gates from $109 \mu$ s to $8.9 \mathrm{~ms}$ for the present survey, allows for measuring later time data for deeper imaging. Locally, the depth of investigation of the method depends on the emitted magnetic moment, the bandwidth used, the subsurface conductivity, and the signal/noise ratio [51]. The TDEM method allows for imaging the conductivity of the subsurface inducting eddy currents in the subsurface [52].

\subsubsection{Inversion Processes}

Data were inverted using the Spatially Constrained Inversion algorithm (SCI) [53]. Each item of TDEM data was interpreted as a 1D earth model (sounding) divided into $n$ layers, each being defined by thickness and resistivity. During the inversion, constraints were applied vertically and spatially on nearby soundings (independent of the flight line and ground clearance). Results were obtained with smooth inversion (25 layers from 0 to $300 \mathrm{~m}$ depth). This inversion method is effective to image complex geological structures with the lowest dependency on the starting model. In addition, the altitude of the transmitter is inverted for and the Depth of Investigation (DOI) was evaluated as a final step of the inversion [54].

\subsubsection{D Geological Model}

Based on TDEM inversion and with the help of the regolith map, a 3D geological model was achieved with GeoModeller ${ }^{\circledR}$ software developed conjointly by the French Geological Survey (BRGM) and Intrepid Geophysics Company. The goal was to obtain the internal structure of the area depicting the different material interfaces that may be prone to landslides.

GeoModeller ${ }^{\circledR}$ was developed to build implicit 3D geological models constrained by geological data [55]. By using the positions of geological limits (the contacts between two geological objects) and structural data (S0, S1, fold axes, etc.), the tool defines the different unit boundaries and builds all the associated geological surfaces. The detailed description and rules can be found in [55]. GeoModeller ${ }^{\circledR}$ was used successfully to produce 3D geological models of complex tectonic structures $[55,56]$.

\subsection{Landslide Susceptibility Analysis: Slope Stability Modeling, Elaboration of Scenarios, Run-out Analysis,} and Spatialization

The landslide susceptibility, hazard, and risk assessment benefited from a substantial literature review $[11,13,15,57-61]$. Landslide susceptibility assessment (LSA) expresses the spatial correlation 
between predisposing terrain factors (slope, land use, superficial deposits, etc.) and the distribution of observed landslides in a territory $[57,62]$. The goal is to produce information about the most probable initiation areas (probable failure) and the possible extension (retrogression and downslope run-out of phenomena, [11,15]). Several approaches allow for assessing landslide susceptibility, from simple (basic susceptibility assessment) to more complex assessment (advanced susceptibility assessment) following the scale of the work $[11,13,15]$. For small sites, it is possible, when sufficient data are available or acquired, to use physically based methods (slope stability modeling by a static approach and/or profile-based approach $[11,15,63])$ and coupled them with a run-out analysis. LSA does not refer to temporality probability. Because there was little information about the historicity, frequency, and intensity of landslides in the target area, it was decided to concentrate the work on susceptibility analysis, taking into account slope failure and run-out. The temporality of phenomena (occurrence within a given period) was not taken into account; in this sense, the analysis can be considered an advanced susceptibility assessment [11,15].

Slope stability modeling is recognized to give more concrete results with more predictive capability than another approaches $[13,15]$. It aims to assess different instability conditions according to different factors (e.g., ground water level, seismic acceleration). The geotechnical analysis was based on the calculation of the limit equilibrium of slopes using a physically based approach (i.e., slice approach; [64]). Results are depicted by a Factor of Safety coefficient (FoS). If the FoS is less than or equal to 1 the ground is considered unstable. In order to answer the questions posed by the municipality, two steps were defined:

1. The first step was based on a 2D analysis of the FoS assessing the various most influential parameters (topography, GWL, geotechnical values). Some scenarios were used along one cross section with tests about excavation and building overload (only taking into account house characteristics). In this way, it was possible to assess the influence of future planning on slope stability;

2. The second step consisted of spatializing the FoS to define the most unstable areas according to a spatialized physically based model (i.e., ALICE $^{\circledR}$ ) developed by the French Geological Survey $[65,66]$. ALICE ${ }^{\circledR}$ is able to support different landslides' geometries, the spatial and inherent heterogeneity of the surficial deposits and geology and their geotechnical parameters, different triggering factors (i.e., GWL and seismicity-PGA), and land use change. The geometry of the studied area is entered as a dataset in raster format: topography, geometry of geological, and/or surficial deposits layers represented by a DTM (i.e., basal surface of the layer). Geomechanical characteristics are associated with each geologic and surficial deposit layer. More details about the tool and its possibility can be found in $[65,66]$;

3. The third step focused on the run-out calculation based on the ALICE ${ }^{\circledR}$ results with a cellular automaton $\left(\mathrm{BORA}^{\circledR}\right)$ developed by the French Geological Survey for the French Indies and Polynesia [67].

For the steps 1 and 2 the Morgenstern and Price [68,69] equations were used; four parameters are requested:

1. Surface topography and internal structure geometry;

2. Effective cohesion $\mathrm{c}^{\prime}(\mathrm{kPa})$;

3. Effective angle of friction $\varphi^{\prime}\left({ }^{\circ}\right)$;

4. Specific bulk unit weight yd $\left(\mathrm{kN} \cdot \mathrm{m}^{-3}\right)$.

The topography is obtained from the DEM Litto3D ${ }^{\circledR}[70]$ obtained by LiDAR technology at a cell size of $1 \mathrm{~m}$. This is a unique and continuous land-sea datum database giving a three-dimensional representation of the shape and position of the soil on the littoral fringe of the French territory (including the French West Indies). Subsoil elements are not described in this product. For the first 
step, the cross section was derived from this DEM. For the second step using ALICE ${ }^{\circledR}$ the cell size of calculation was $10 \mathrm{~m}$ following previous works in Martinique [34-37]. The internal structure was derived from the regolith map and the 3D geological model elaborated specifically for this research. For each material, the geotechnical values were defined following the previous sensitivity analyses performed near this area [34-37]. For the third step, the tool took into account the distance of the flowing mass and its spreading. It did not take into account the temporality of the phenomena. From the results obtained with ALICE $^{\circledR}$, the model deals with the probable displacement of the masses for each cell. The hypotheses are: (1) a soil mass moves a priori along a steepest slope profile; (2) the gain or loss of energy of the moving mass is a function of the value of the slope; (3) the energy of the mass is capped; (4) the moving mass can deviate from steepest slope profile; (5) this gap may consume energy [70]. This energy is the engine of the run-out. As long as the energy is positive, the mass moves; when the energy is canceled the moving mass stops. The total energy cannot be lower than 0; it is defined according to the slope and accumulates from one cell to another. For each cell, the energy is computed and associated with one probability. Because the parameters of the models (energy and favorable slopes to run-out) were calibrated and validated for different landslide types on the island, no sensitivity analysis was necessary. The parameters can be found in [67].

\subsection{Comparison with Existing Landslide Expert Maps}

The different simulated maps obtained are compared and discussed with a direct landslide susceptibility/hazard map produced by the PPR approach (Plan de Prévention des Risques-Risk Prevention Plan). The PPR is the official legal procedure since 1995 in France [71]. The goal is to analyze and delineate hazard areas, exposed areas with major stakes, vulnerable and at-risk areas (e.g., a municipality, a catchment) in order to give some prescriptions regarding town planning, building, and management $[12,72]$. The PPRs are supported by the State and are decided by the prefects. They are carried out by the departmental services of the State at the scale of 1:10,000 or 1:25,000, depending on the degree of urbanization. Different documents compose the PPR. They are detailed in Leroi [12,72]. The PPR is composed of:

1. A zoning plan, resulting from the crossing of susceptibility or hazards (when information about the frequency and intensity of phenomena is available) and issues identifying areas that cannot be built on or only with special developments;

2. A report presenting the studies, the results and justifications of the different zones and regulations included, and those made compulsory;

3. A regulation describing the constructive and/or urban planning constraints in each zone.

For this study, only a map with prescriptions and constraints are used. The methodology used to obtain this map required a global overview of the area to identify sectors with homogeneous environmental characteristics for each landslide type. The methodology advised us to take into account the possibilities of landslide developments for the coming 100 years [12,72]. However, for the studied area, no events were reported in the French official database before the tropical storm in 2009 [39]. In consequence, the established rules of the landslide hazard map are based on feedback from other landslide observations on the island [70]. Thus, it would be better to use the term Landslide Expert Susceptibility Map (LEM) to avoid any confusion. Five degrees of landslide susceptibility were defined (S1 $\rightarrow$ S5, Table 1). 
Table 1. Susceptibility class used for the Landslide Expert Susceptibility Map produced for the PPR in La Trinité.

\begin{tabular}{ll}
\hline \multicolumn{1}{c}{ Susceptibility Class } & \multicolumn{1}{c}{ Regulation } \\
\hline $\begin{array}{l}\text { S5: Very high } \\
\text { susceptibility }\end{array}$ & $\begin{array}{l}\text { Environmental conditions are very favorable to slope instability. High possibility of } \\
\text { landslide occurrences for the next } 100 \text { years. Future human and socioeconomic } \\
\text { developments are forbidden. Expropriation process is possible. }\end{array}$ \\
\hline S4: High susceptibility & $\begin{array}{l}\text { Environmental conditions are very favorable to slope instability. High possibility of } \\
\text { landslide occurrences for the next one hundred years. Future human and } \\
\text { socio-economic developments are forbidden except as specified in the legal } \\
\text { regulation document. Expropriation process is possible. }\end{array}$ \\
\hline S3: Moderate & $\begin{array}{l}\text { Environmental conditions are moderately favorable to slope instability. Moderate } \\
\text { possibilities of landslide occurrences for the next 100 years. Prescriptions are } \\
\text { necessary and global development studies are required. In general, mitigation } \\
\text { works are essential for future human and socioeconomic developments of the area. }\end{array}$ \\
\hline S2: Low susceptibility & $\begin{array}{l}\text { Environmental conditions are lowly favorable to slope instability. Low possibility } \\
\text { of landslide occurrence for the next } 100 \text { years. Future human and socioeconomic } \\
\text { developments of the area are possible and can be determined with specific } \\
\text { attention to each specific case. }\end{array}$ \\
\hline S1: Null susceptibility & $\begin{array}{l}\text { Environmental conditions are not favorable to slope instability. No possibility of } \\
\text { landslide developments for the next } 100 \text { years. Future human and socioeconomic } \\
\text { developments of the area are possible and cannot be subject to specific attention. }\end{array}$ \\
\hline
\end{tabular}

\section{Results}

\subsection{Regolith Map and Weathered Degree}

The regolith map, representing the different formations at the surface (up to 10-15 $\mathrm{m}$ ) and their weathered grades based on field observations and TDEM interpretations is displayed in Figure 6A.

In the area, at 1: 50,000 of work, geologists have mapped two main types of formations (andesite and basalt of Vert-Pré; [46]). If these formations correspond to the major steps of this part of the island formation [38], locally there are variations of facies (i.e., another type of lava or allochthonous deposits from implementation processes other than lava). Thus, in the upstream of the area, within the large sets of andesite, colluviums and some traces of tuff were observed. The colluviums come from either the erosion phase or assumed large landslides in terms of geomorphological features (upstream part in circle arc, hummocky terrain, or lobate forms). In the downstream area, the second set was carved on basalt of Vert-Pré. This lithology was difficult to observe because the deposits may be thick and colluviums can cover the rock. Few outcrops, located in gullies (more than $10 \mathrm{~m}$ deep), made it possible to observe them. Thus, in this large ensemble weathered basalts, tuffs, colluviums, and, locally, a recent andesite flow are juxtaposed. For both areas, the gullies are usually filled with alluvial formations. Each geological formation is subdivided according to the weathering degree, following Figure 5. To facilitate the mapping and the weathered degree representation, horizons with small thickness and propinquity were aggregated. Therefore, three representations were retained with:

1. Horizons $\mathrm{H} 5$ and $\mathrm{H} 4 \mathrm{c}$ formed the soft surface;

2. Horizons $\mathrm{H} 4 \mathrm{~b}$ and $\mathrm{H} 4 \mathrm{c}$ constituted the strongly weathered part;

3. Horizons $\mathrm{H} 4 \mathrm{a}$ and $\mathrm{H} 3$ represented healthy rocks with supergene origin cracking from low to medium intensity.

\subsection{TDEM Interpretation}

The obtained resistivity profiles were confronted to the regolith map. Figure $6 \mathrm{~A}, \mathrm{C}$ shows two resistivity profiles intersected where the mapped formations boundaries are reported. A good correlation was observed between the imaged resistivity contrasts at the surface and the different formations observed in the field (Figure 6B,D). 
More deeply, some lithology showed internal resistivity variations (Figure 6A,C). For basalt, two different elements were observed with one layer with resistivity lower than $10 \Omega \mathrm{m}$ and one layer with resistivity upper than $20 \Omega \mathrm{m}$. We assume that these differences are due either to internal water circulation or to a pronounced weathered degree for the low resistivity layer, whereas the layer with higher strength resistivity constitutes the solid substratum. For andesite formations, some internal contrasts are fuzzy and cannot be analyzed easily. Nevertheless, it is possible to define recent and old andesite formations. Recent andesite formations had relatively high resistivity (more than $20 \Omega \mathrm{m}$; Figure 6A), whereas in older andesite the resistivity values increase with depth (up to $30 \Omega \mathrm{m}$ ) to a maximum depth of $30 \mathrm{~m}$ and then decrease (below $10 \Omega \mathrm{m}$ ), then increase again and stabilize around $30 \Omega \mathrm{m}$ at $75 \mathrm{~m}$ depth. The surface differences up to $10 \mathrm{~m}$ depth are probably due to the supergene weathering of the rock. Then, more deeply, we are probably looking at different phases of lava flows fitting into each other with fossilized phases of weathering. These weathering fronts can be propitious to internal water circulation, decreasing the resistivity recorded by the TDEM dispositive [24]. Table 2 depicts the different formations and their resistivity range. These values were used to improve the 3D geological model.

Table 2. Formations identified by field observation, TDEM interpretations and modeled in the 3D geological model.

\begin{tabular}{|c|c|c|c|}
\hline Description of Material & Thickness & Resistivity Boundaries & $\begin{array}{l}\text { Age Formation } \\
\text { Estimated } 1,2\end{array}$ \\
\hline Alluviums or colluviums & Lower than $10 \mathrm{~m}$ & From a few $\Omega \mathrm{m}$ to $20 \Omega \mathrm{m}$ & Quaternary/Present \\
\hline $\begin{array}{l}\text { Recent andesite with } \\
\text { relatively high resistivity }\end{array}$ & Lower than $10 \mathrm{~m}$ & More than $20 \Omega \mathrm{m}$ & $2.1 \mathrm{Ma}-1.5 \mathrm{Ma}$ \\
\hline Tuffs & Lower than $10 \mathrm{~m}$ & More than $20 \Omega \mathrm{m}$ & 2.1 Ma-1.5 Ma \\
\hline $\begin{array}{l}\text { Andesite (probably } \\
\text { weathered at the top and } \\
\text { compact at the bottom) }\end{array}$ & More than $50 \mathrm{~m}$ & $\begin{array}{l}\text { From } 8 \text { to } 20 \Omega \mathrm{m} \text { for the } \\
\text { upper part; from } 10 \text { to } 35 \\
\Omega \mathrm{m} \text { for the bottom part }\end{array}$ & $5.5 \mathrm{Ma}-2.2 \mathrm{Ma}$ \\
\hline Conductive basalt & From $25 \mathrm{~m}$ to $100 \mathrm{~m}$ & Lower than $10 \Omega \mathrm{m}$ & $16.8 \mathrm{Ma}-8.48 \mathrm{Ma}$ \\
\hline Resistant basalt & Model basis & Higher than $20 \Omega \mathrm{m}$ & $16.8 \mathrm{Ma}-8.48 \mathrm{Ma}$ \\
\hline
\end{tabular}

Thus, airborne EM allows for determining the extents and thicknesses of the different formations; this constitutes a significant result in the use of the airborne TDEM method for supporting/completing geological mapping.

\subsection{D Geological Model}

Based on the interpretation of resistivity a 3D geological model was performed (Figure 7B). 3D GeoModeller ${ }^{\circledR}$ gives a geological model using implicit functions [44]. The surface is not directly known but can be deduced from a property. Modeling consists of finding an expression of $f$, computable at every points and representing the countered surface of $f$. GeoModeller ${ }^{\circledR}$ interpolates the scalar field with a co-kriging method to interpolate several variables, knowing their spatial correlation. Geological surfaces cannot be given analytically, but explicitly for a more realistic representation. 


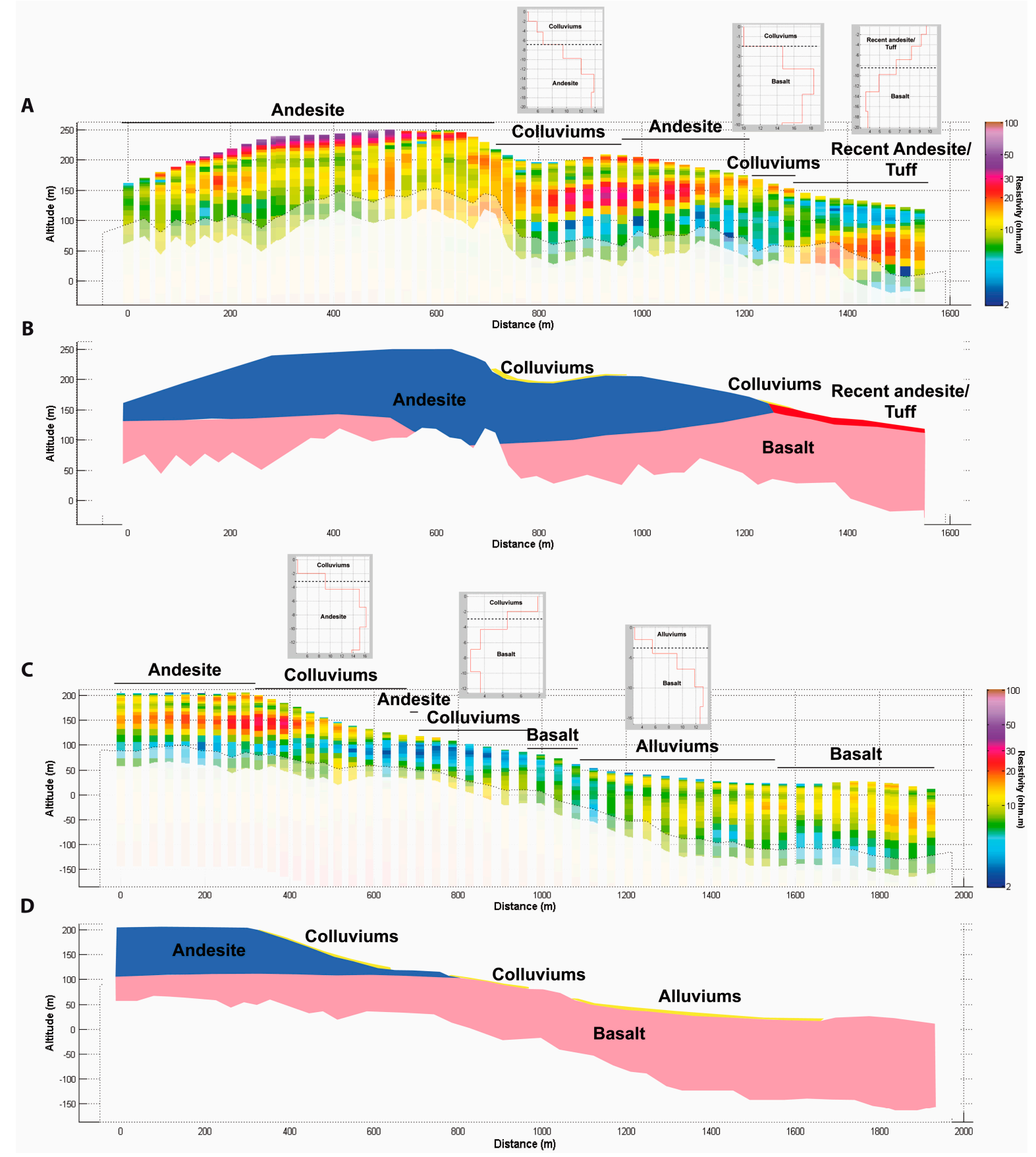

Figure 6. Resistivity results and interpretations. (A) Resistivity profile $n^{\circ} 1$; (B) resistivity profile $n^{\circ} 1$ interpretation; (C) resistivity profile $\mathrm{n}^{\circ} 2$; (D) resistivity profile $\mathrm{n}^{\circ} 2$ interpretation.

The model was built in a geo-referenced system; it took into account (1) the regolith map; (2) a DEM based on the Litto3 ${ }^{\circledR}[70]$; (3) interpretation of resistivity from EM analysis with integration of pseudostratigraphic pile, intended to image the geology and structural relationships as best as possible [54,55]; and (4) geological contacts and orientations deduced from EM interpretations. Forty sections in the study area were used to locate crossing points and orientations for each lithology leading to the 3D model. When the internal contrasts in a formation are very fuzzy, they are not taken into account. The model intended to image the geology and structural relationships as best as possible. Given that GeoModeller ${ }^{\circledR}$ used implicit modeling, the model can be computed to every 
desired resolution. Figure $6 \mathrm{~B}$ shows the model with a cell size of $40 \mathrm{~m}$. Because the resolution is less than $10 \mathrm{~m}$, it is not possible to see very thin tiff formations.
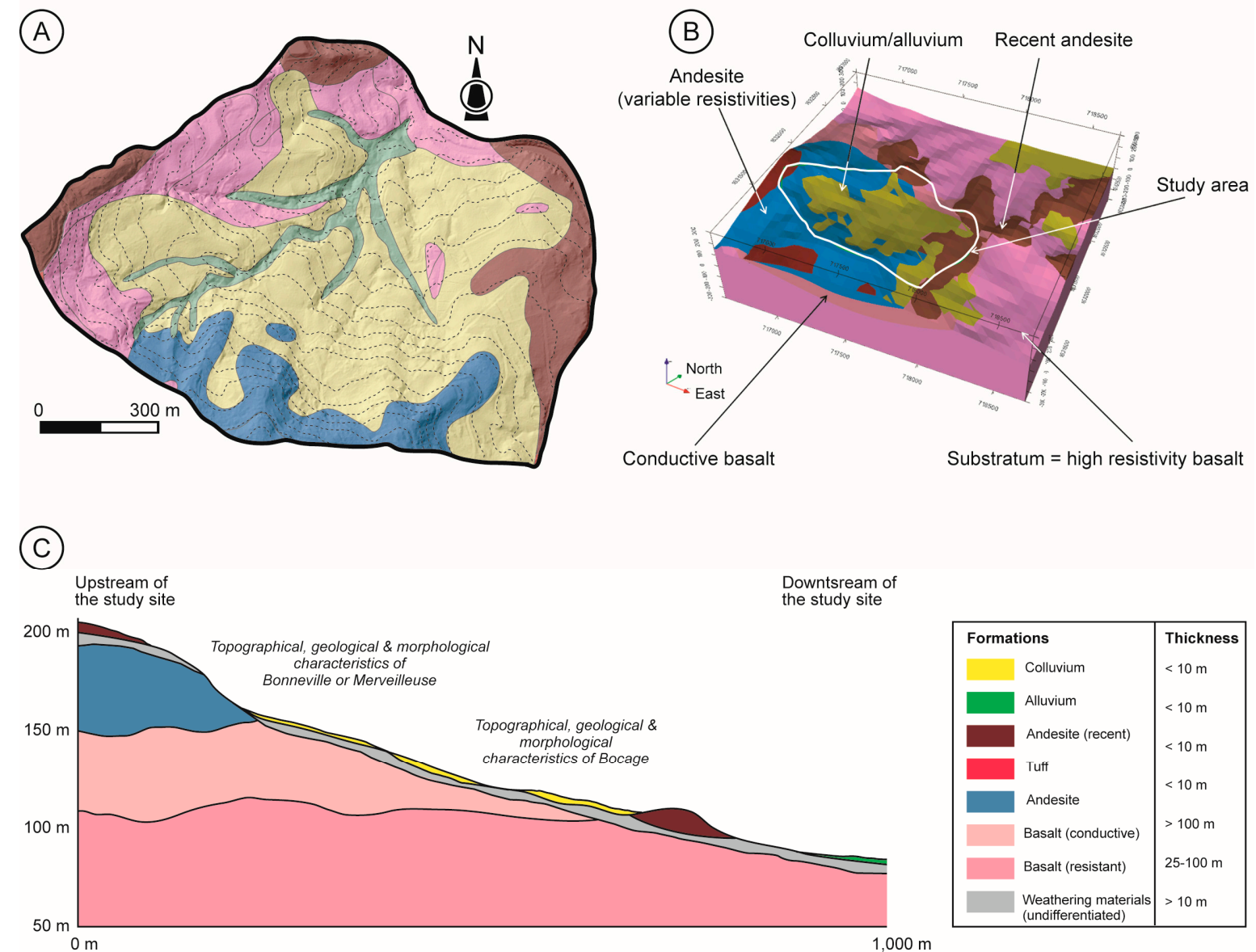

Figure 7. (A) Regolith map based on field survey and TDEM interpretations; (B) geological 3D model obtained from the GeoModeller ${ }^{\circledR} ;(\mathbf{C})$ synthetic cross section of the test site obtained with (A) and (B).

Based on the 3D model, regolith map, and field survey, a cross section synthesizing the different information was obtained (Figure 7C). This interpretation is a non-negligible aid to the landslide susceptibility assessment.

\subsection{Landslide Susceptibility Analysis: Sensitivity Analysis, Scenario, and Spatialization}

According to observations and previous works [34-37,39,43], two types of instability were taken into account: shallow landslides (rotational and translational) with a slip surface between three and four meters and occurring generally in colluvium formations, and deep landslides (rotational and translational) with a slip surface between eight and 10 meters and occurring in weathered materials [34-37,39,73]. For both landslides, models were constructed by imposing the slip surface at the interface between colluviums and weathered materials or at the interface between weathered materials and substratum (andesite or basalt). For each material, Table 3 depicts the different geotechnical values derived from antecedent technical works performed near the test site in the same type of material [34-37,43]. 
Table 3. Geotechnical values retained for modeling step.

\begin{tabular}{cccc}
\hline Formations & $\begin{array}{c}\text { Cohesion } \\
\left(\mathbf{c}^{\prime} \text { in } \mathbf{~ P a}\right)\end{array}$ & $\begin{array}{c}\text { Angle of Friction } \\
\left(\boldsymbol{\varphi}^{\prime} \text { in }{ }^{\circ}\right)\end{array}$ & $\begin{array}{c}\text { Specific Bulk Unit } \\
\text { Weight }\left(\gamma \mathbf{d} \text { in } \mathbf{~ k N} \cdot \mathbf{m}^{-3}\right)\end{array}$ \\
\hline Colluviums & 8 & 15 & 15 \\
Weathered & 12 & 18 & 18 \\
materials & 40 & 35 & 20 \\
Andesite & 50 & 38 & 25 \\
Basalts & & & \\
\hline
\end{tabular}

\subsubsection{Analysis of 2D Slope Stability Models}

The hypothesis is that landslides (shallow and deep) are controlled by the rise of groundwater level in regolith; this level is a function of precipitation, as observed in 1989 by [43]. Unfortunately, due to the lack of regular temporal data between landslides and precipitation, it was not possible to perform a representative hydrogeological model taking into account precipitation. Thus according to [34-37,43], two levels of GWL (imposed empirically) were used: (1) one level favorable to slope stability equivalent to low material saturation (i.e., $\mathrm{GWL}=0.1$ ); (2) another level very favorable to slope instability equivalent to high material saturation (i.e., $\mathrm{GWL}=0.9$ ).

To take into account the effects of future developments two scenario were tested. The first scenario consisted of manually modifying the topography on a location considered prone to landslide (convex topography with rapid slope change). Therefore, three locations were chosen (Figures 8 and 9). The second scenario assessed the building vertical overload according to the French standards of building operating load and the values to introduce into the models [74]. The vertical overload characteristics were defined for a house with a surface of $100 \mathrm{~m}^{2}(\mathrm{~L}=20 \mathrm{~m} ; \mathrm{W}=5 \mathrm{~m})$ with one floor, one staircase, and one balcony, resulting in a constant overload of $21.5 \mathrm{kPa}$ (i.e., $2.15 \mathrm{t} . \mathrm{m}^{-2}$ ).

Figures 8 and 9 depict the results for the different scenarios for shallow and deep landslides. Results for rotational and translational landslides were merged to show potentially unstable sectors in a synthetic way.

For Scenario 1, with current topography, in dry conditions the FoS is high with a minimum FoS of 1.45 for shallow and deep landslides. The rise of GWL from 0.1 to 0.9 , representing the saturated conditions favorable to landslide activation in rainy season [43], decreases the minimum FoS to 0.92 and 0.86 for shallow and deep landslides, respectively. In more detail, in both cases, the slope upstream is the most favorable for both types of instabilities, while the downstream part, corresponding to lower slope angles, is less prone to landslides.

For Scenario 2, with excavation, in the case of dry saturation for shallow landslides, few changes about the FoS were noticed. The lower part of the slope, near the third excavation, appears to be more favorable to landslides, with a minimal FoS rising from 2.05 to 1.45 , meaning a low probability of failure. In saturated conditions, as expected, the situation is little more complex. Upstream of the three excavations, the FoS decreases below one, meaning recurrent slope instability with high GWL. In more detail, locations with moderate $(1<\mathrm{FoS} \leq 1.2)$ and low susceptibility $(1.2<\mathrm{FoS} \leq 1.5)$ are more numerous, particularly in the earthwork locations and in the downstream part of the slope. Finally, slope failure characteristics are not very high, with a maximum length of $7 \mathrm{~m}$ and maximum depth of $3 \mathrm{~m}$, and are located on the front of the banks.

For deep landslides, the FoS decreases slightly in the upper part of the slope (rising to 0.86 to 0.81), while in the downstream part of the slope few modifications are noticed (Figure 8).

For the upper part, the length represented by low FoS is shorter than in Scenario 1. Modifying the slope shape by excavation decreases the thicknesses of colluviums and weathered materials, lightening the supposedly unstable masses. Similarly, it is assumed, in the model, that the water table is folded towards the topographic base. The consequences are (1) a modification of charges; (2) a GWL redistribution; and (3) a new distribution of the different strengths at the location of the second excavation work. Thus, a clear increase of the FoS is noticed (from 0.86 to 1.35 in saturated conditions). 
For the downstream part of the slope, slight modifications were noticed with a larger length computed with a FoS around 1.40 than in Scenario 1, in particular at the location of the third excavation work.

The excavations with building overload taken into account in Scenario 3 do not change the results of Scenario 2, for dry and saturated conditions for each failure type. Overloading, calculated for a typical residential cinderblock, characteristic of the island, is not an aggravating factor of slope instability. Thus, water (by way of the GWL) emerges, for these scenarios, as the main triggering factor. Therefore, it will be the subject of special attention in case of development.
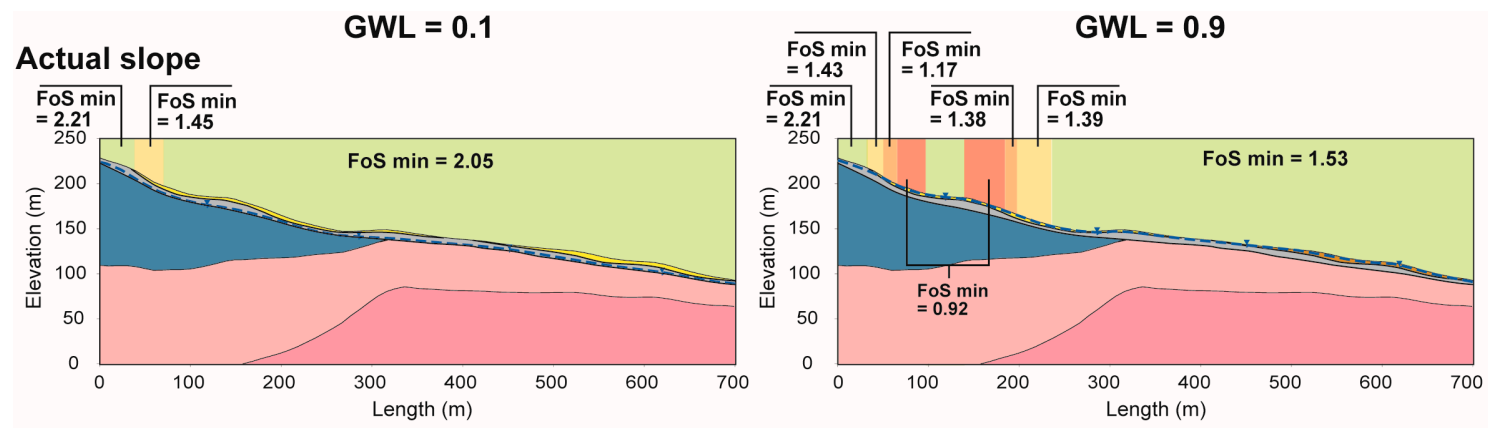

\section{Scenario 01: with excavation}
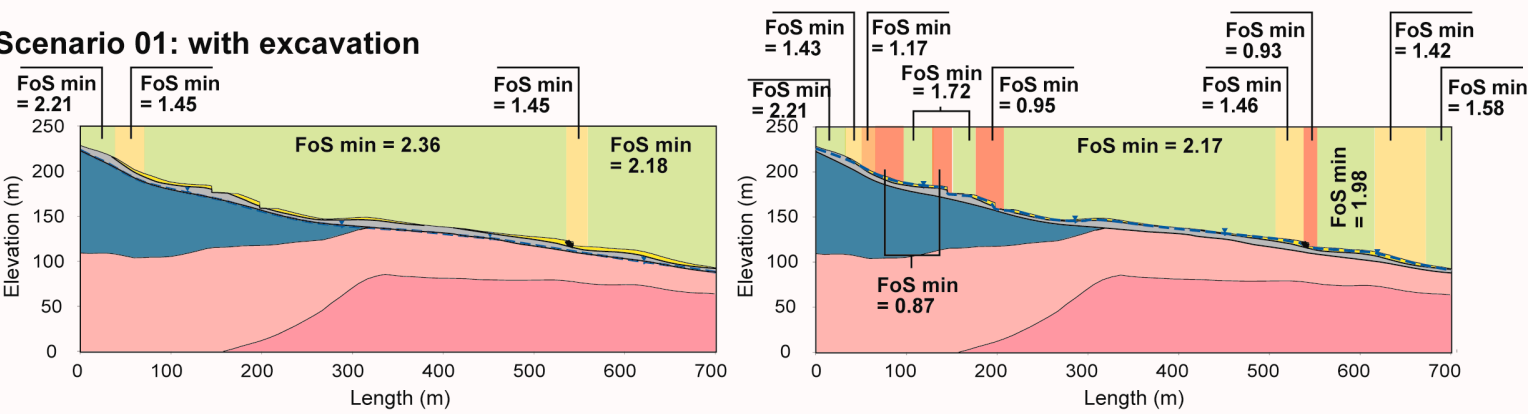

Scenario 02: with excavation + building overload
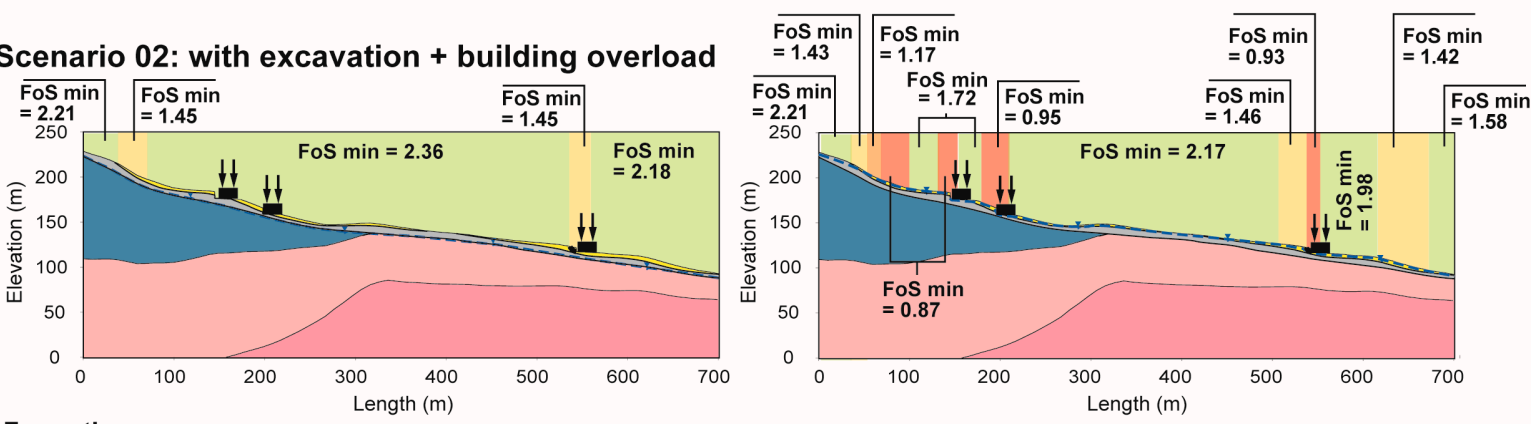

Formations

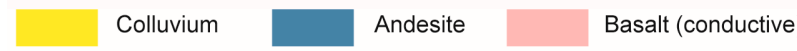

Instability class

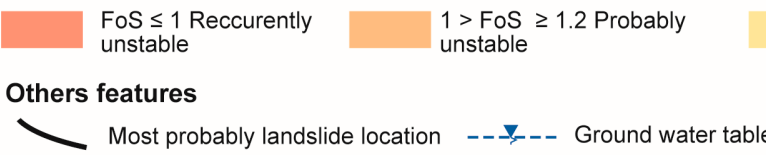

Figure 8. Slope stability analysis for shallow landslides (translational + rotational) on a representative cross section. The location of the cross section is given in Figure 10. 
$\mathrm{GWL}=0.1$

\section{Actual slope}

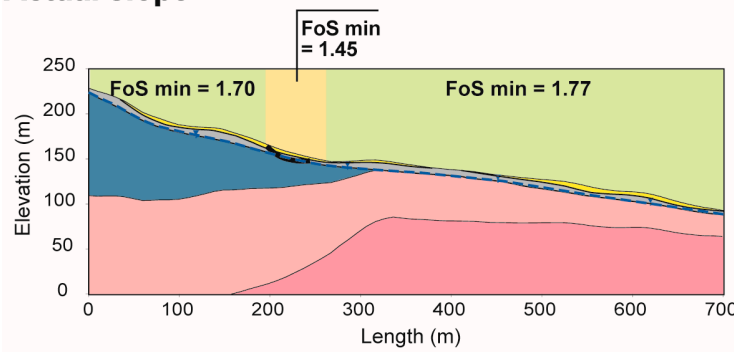

\section{Scenario 01: with excavation}
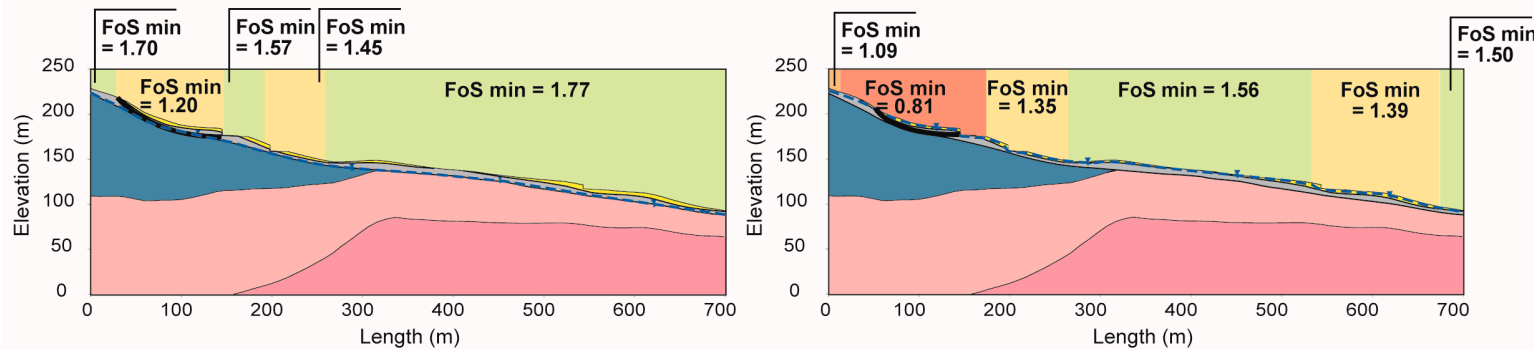

Scenario 02: with excavation + building overload
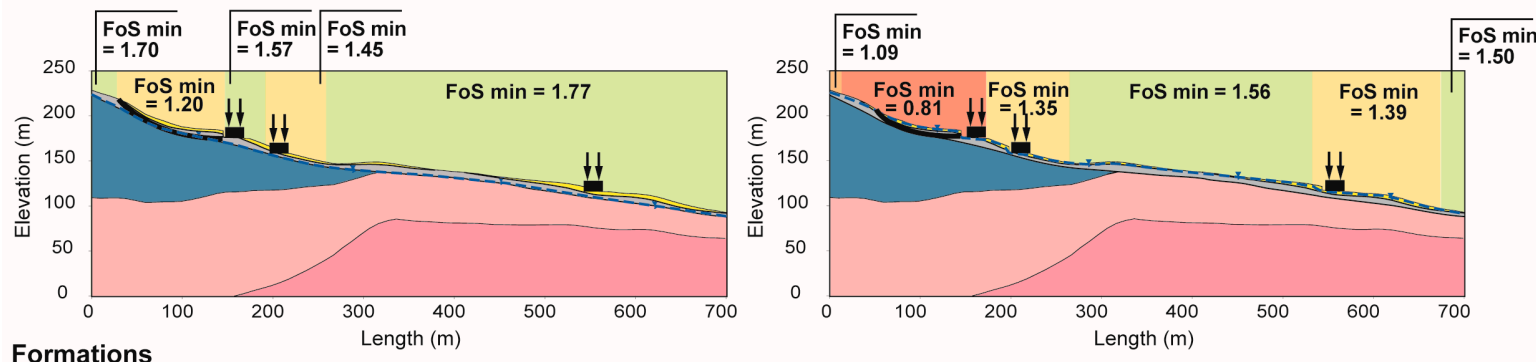

Formations

Colluvium

Andesite

Basalt (conductive)

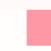

Basalt (resistant) Weathering materials
(undifferentiated)

\section{Instability class \& associated hazard class}

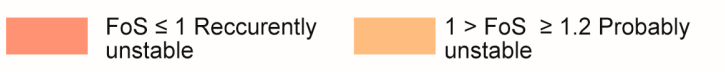

$1.2>$ FoS $\geq 1.5$ Probably conditionnaly unstable

FoS > 1.5 Probably still unstable unstable

\section{Building (house) overload}

Figure 9. Slope stability analysis for deep landslide (translational + rotational) on representative cross section. The location of the cross section is given in Figure 10. 


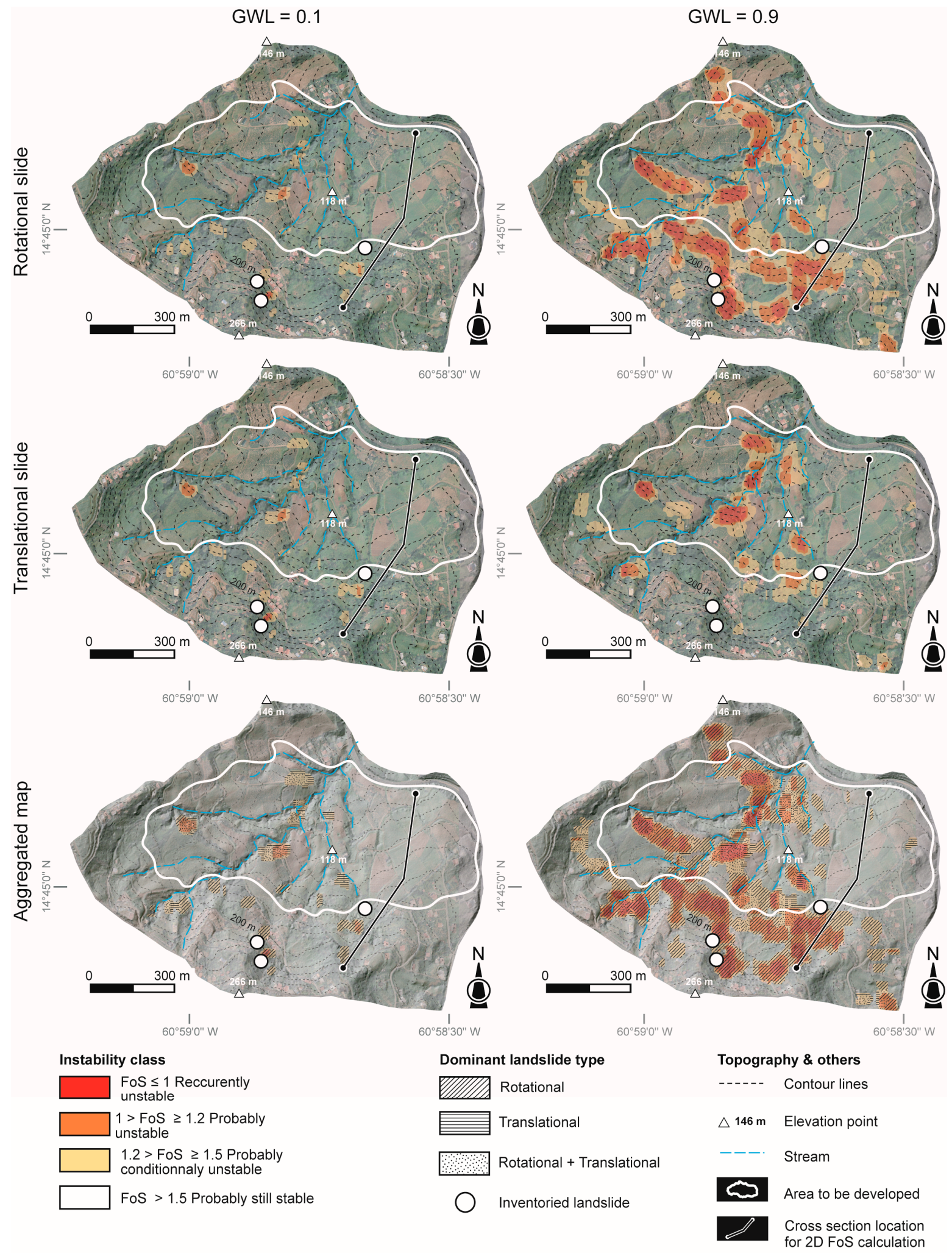

Figure 10. Slope stability maps obtained with $\mathrm{ALICE}^{\circledR}$ for shallow landslides (translational + rotational) for dry and saturated conditions (coordinates are expressed in Lat/Long; projection WGS84 UTM 20N-EPSG 32620). 


\subsubsection{Analysis of Slope Stability and Run-Out Spatialization}

The goal of the FoS and run-out spatialization was to provide an additional answer compared to the $2 \mathrm{D}$ cross section analysis.

FoS are computed with the same type of information used in the previous step. New information must allow the enhancement of the LEM of the area represented in moderate class. This type of class has large uncertainties in the framework of town planning. It must be emphasized that knowing the thicknesses of the regolith and materials from TDEM data is a real asset for this study. If the geotechnical values and different interfaces are the same as in the previous step, it is necessary to note that the excavations and overload scenarios were not taken into account in this step; ALICE $^{\circledR}$ does not take into account this type of hypothesis. However, the landslide types were discriminated. Indeed, if for the 2D analysis there were small differences in the calculations for the two landslide types, the spatial calculation, on currently topography, showed that some areas that were more complex.

Figure 10 depicts the results for shallow landslides (translational and rotational). In both cases, few locations with moderate $(1<$ FoS $\leq 1.2)$ and low susceptibility $(1.2<$ FoS $\leq 1.5)$ were calculated in dry conditions. In saturated conditions, steep slopes carved in andesite lithology with a weathered cover and slopes covered by colluviums become unstable, especially near Morne-Congo and Bonneville. The site of Merveilleuse can be separated with a stable (FoS > 1.5) part upstream and highly unstable $(1 \leq$ FoS) areas, especially convex slopes, near the confluence of streams (Figure 10). Only the site of Bocage appears as stable in the models for shallow landslides. Among the landslide inventory, for the scenario with high GWL (GWL $=0.9)$, two events are located in a recurrently unstable area, whereas one event is located in the limit of probably unstable area. The predictive power of the failure initiation modeling for shallow landslide can be considered good.

For deep landslides (Figure 11), in dry conditions, the areas classified as moderate $(1<\mathrm{FoS} \leq 1.2)$ and low susceptibility $(1.2<$ FoS $\leq 1.5)$ are significantly different from shallow models, especially for the low susceptibility class with a computed surface increasing about $45 \%$. It should also be noted that the steep slopes in the andesite, near Morne-Congo, have some locations with a FoS $\leq 1.5$, which means that stability may become precarious depending on triggering or aggravating factors' changes. Results obtained under saturated conditions confirm this trend. Rising GWL in the model allows the FoS to drop significantly for certain locations, passing from stability to recurrent instability (decrease of the FoS more than 1). Thus, with a high GWL, the considered surfaces with FoS $\leq 1$ occupy $0.18 \mathrm{~km}^{2}$ ha (i.e., $18 \%$ of the area). If the moderate class is added, $0.35 \mathrm{~km}^{2}$ is represented as unstable or probably unstable; $54 \%$ more of the modeled surface is unstable or probably unstable than for shallow landslides. If we zoom in to the area where development is planned $\left(0.38 \mathrm{~km}^{2}\right), 22 \%$ are modeled with a FoS $\leq 1$; like the shallow landslides models, the Bocage and Merveilleuse areas appear least threatened by possible landslides. The three inventoried landslides are located in a recurrently unstable area. Even if the inventoried landslides are shallow, the models can be considered to have high predictive power. 


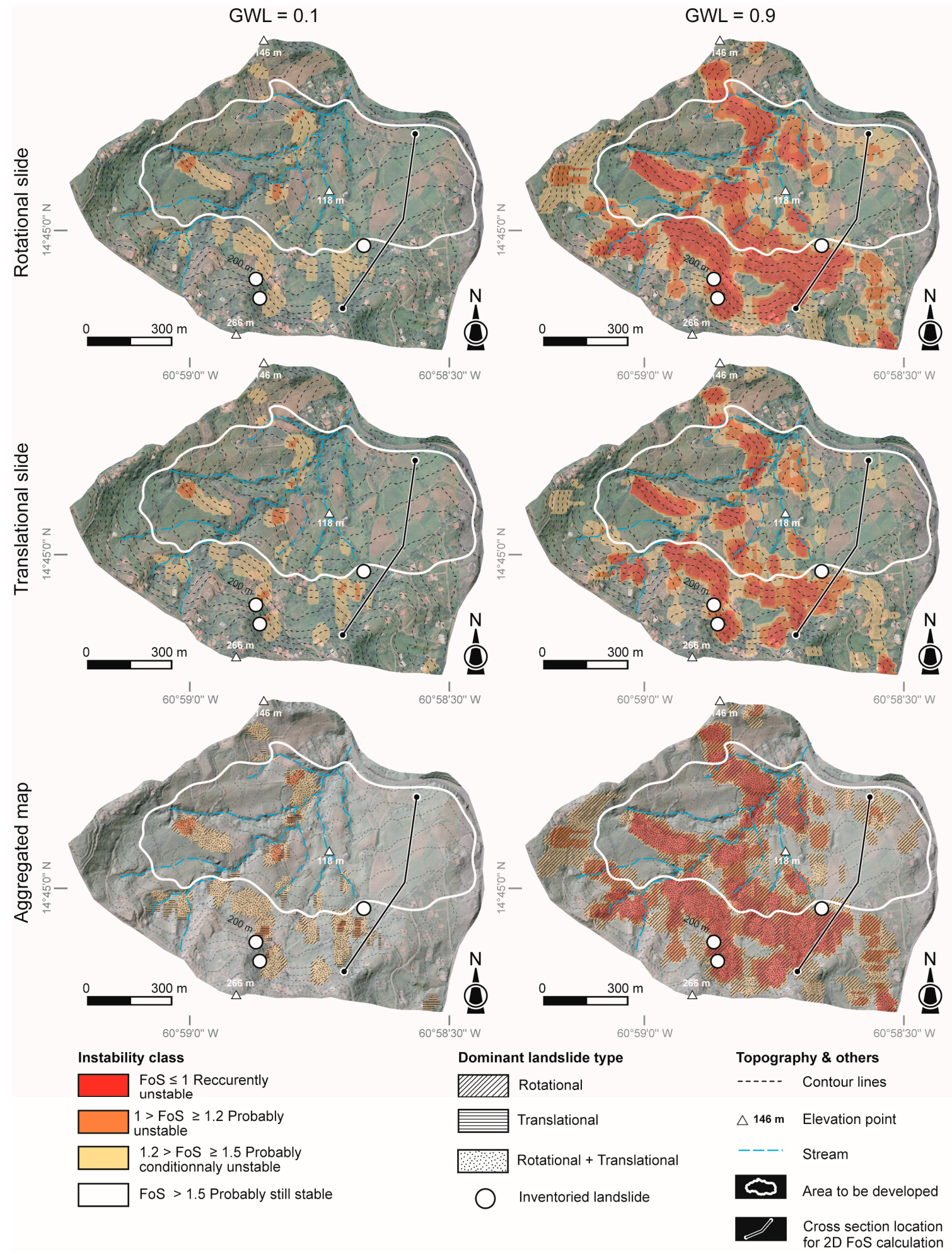

Figure 11. Slope stability maps obtained with $\mathrm{ALICE}^{\circledR}$ for deep landslides (translational + rotational) for dry and saturated conditions (coordinates are expressed in Lat/Long; projection WGS84 UTM 20N-EPSG 32620).

Run-out assessments were computed from the cells with FoS $\leq 1$ for shallow landslides and deep landslides for the worst scenario (i.e., $\mathrm{GWL}=0.9$ ). The maximum run-out distance retained was $80 \mathrm{~m}$ for shallow landslides and $80 \mathrm{~m}$ for deep landslides, following previous studies and calibration for 
shallow landslides and deep landslides [33-36,38,70]. This distance took into account the maximum run-out distance observed for each type of phenomenon plus a safety distance of $10 \mathrm{~m}$ and $20 \mathrm{~m}$ for shallow and deep landslides, respectively. The run-out distance for shallow landslides was considered longer than for deep landslides because with this type of instability materials can become fluid with high saturation, corresponding to the worst scenario of instability. For deep landslides, with the masses being more plastic, the run-out distance was considered more restricted. Figures 11A and 12B show the results for each landslide type with the surfaces covered by modeled failure and run-out.

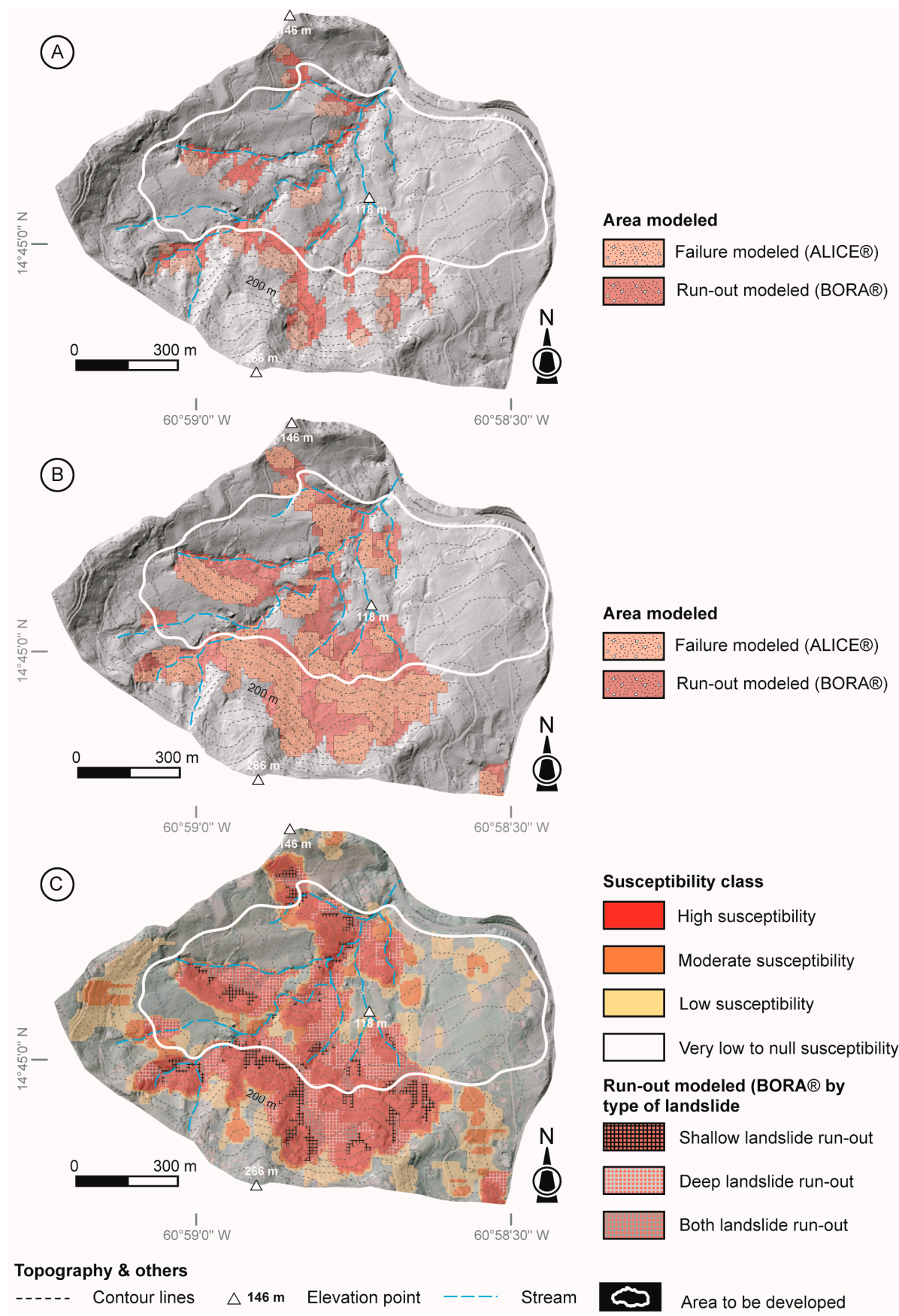

Figure 12. (A) Modeled translational landslide map representing shallow and translational landslides with failure and run-out; (B) modeled rotational landslide map representing shallow and deep landslides with failure and run-out; (C) unified modeled map representing modeled failure and modeled run-out (coordinates are expressed in Lat/Long; projection WGS84 UTM 20N - EPSG 32620). 
Finally, to obtain an advanced landslide susceptibility map, the different results were merged as a basic principle to keep for each cell the most favorable class identified for landslides (failure or run-out; Figure $12 \mathrm{C})$ for the worst scenario $(\mathrm{GWL}=0.9)$.

\subsubsection{Comparison with LEM}

The Landslide Expert susceptibility map (LEM) (PPR; Figure 13) shows a large representation of the moderate class $(81.7 \%$ of the surface of the site). Without rejecting the work done by experts about 10 years ago, it should be noticed that this class appears overrepresented within the area (Figure 13A).

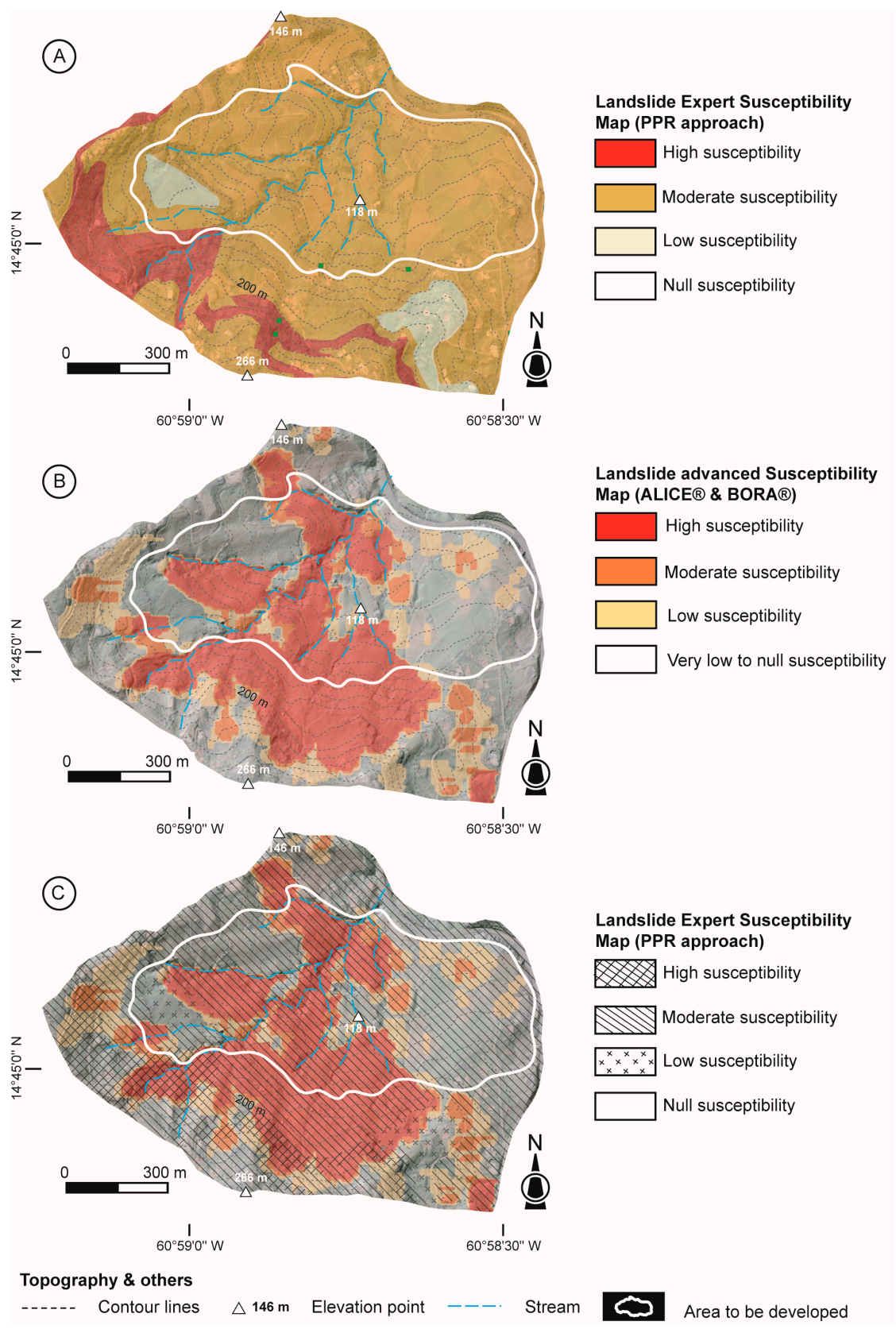

Figure 13. (A) Landslide Expert Susceptibility Map produced by the PPR approach; (B) combined landslide advanced susceptibility map produced with $\mathrm{ALICE}^{\circledR}$ and BORA ${ }^{\circledR}$ (for shallow and deep; translational and rotational landslides); (C) superposition of the two maps (A,B). (Coordinates are expressed in Lat/Long; projection WGS84 UTM 20N-EPSG 32620.) 
This map was built with less accurate data and for a scale of 1: 20,000, while the maps produced in this work benefit from more accurate data, confirmed by field observations. Figure 13 shows the common points and points of differences between the LEM map and the modeled map.

$0.43 \mathrm{~km}^{2}$ are recognized as stable by the modeled map, while they are mapped in low, moderate or high susceptibility class in the expert map. Only $0.2 \mathrm{~km}^{2}$ ha are common between the expert map and the modeled map for the high susceptibility class. For the landslides inventoried, it is possible to observe a good recognition of events by the model, while the events are not included in the high susceptibility class in the expert map. Lastly, at first glance, the expert map appears to be out of date, but with regard to the terrain and our observations it seems necessary to underline that the gully and near-stream areas do not appear in the strong or moderate susceptibility classes in the modeled map. Nevertheless, these locations must appear in the high or moderate susceptibility classes because of the steep slopes and strong gulling. This type of reasoning, based on expert/model comparison, will be taken into account for indicative documents.

\section{Discussion and Recommendations}

The approach developed in this study is essential in the framework of landslide hazards and risk assessment for future development in the French West Indies. The latter was based on multiple skills of geologists, geomorphologists, geophysicists, and modelers. It is clear that these types of associated skills are rarely used to study an area prone to landslides before development. However, the results show that by combining these competencies in targeted locations, it is possible to improve the zoning and decrease the uncertainty about the areas to be developed.

Thus, the approach allows for defining (1) the internal structure of the complex lithology, superimposing different lava materials and weathering covers; (2) the triggering conditions of different types of landslide characteristic of this environment (i.e., Ground Water Level); and (3) the role of environmental changes by anthropic works on slope stability. This type of reasoning tends to support the conclusions elaborated by [10-15] to better take into account the role of anthropogenic activities on landslides. However, if the approach seems promising, before we give some indications for the future development of the area, several methodological points and results require discussion.

\subsection{TDEM and Its Application}

The use of TDEM is still rare to analyze landslides and assess landslide-prone areas. It is clear that the French West Indies enjoy full coverage, which is currently exploited. However, this use requires specific and challenging processing for these environments.

Indeed, firstly, the ground clearance of the loop was obtained by degrading the available $1 \mathrm{~m}$ Digital Elevation Model to a $25 \mathrm{~m}$ grid (consistently with the AEM footprint) and subtracting it from the DGPS elevation; we did not use the data from the laser, which proved to be biased in such a topographic environment. Tilt measurements were processed, taking into account the local topography in order to consider an effective tilt at each TDEM data location [75]. As part of an environmental study in an anthropized area, particular attention was paid to properly removing noise from the TDEM data. They were processed with a singular value decomposition filter [76]; in addition, manual editing was done, mainly to remove inductive/galvanic coupling noise. Finally, inversion parameters were tuned for near-surface imaging.

The second essential point concerns the results of the TDEM. It is accepted that the device is calibrated and validated to properly recognize objects in deep surface [76], but for this study, it was a challenge to recognize the surficial formations and the regolith a few meters thick. To carry out this action, field observations have been a valuable aid to assess the different components of the soil, the regolith, and the substratum. This study is therefore complementary to the recent research on the analysis of materials susceptible to landslides completed over the last three years by the BRGM on the French West Indies [34-37]. 


\subsection{Models and Hypothesis}

The different models computed in this study have taken up the different triggering hypotheses for landslides near the area with: (1) an increase of the water table and (2) a modification of the topography by anthropic actions $[36,43]$. However, even if the results can be considered satisfactory, the models simplify certain factors, in particular:

1. The formation thicknesses were derived from the TDEM analysis and the 3D model obtained by GeoModeller $^{\circledR}$. Despite efforts to obtain the most accurate data possible, it is necessary to have a minimum of drilling or information to "calibrate" the thicknesses from the analysis of TDEM images. This helps limit the uncertainties related to the local geological context. For this research, the recent results from nearby sites, added to the exhaustive field phase, made it possible to overcome this step.

2. The maps obtained by modeling can be considered advanced susceptibility maps because they do not take into account the intensity and the return periods of the events indispensable to assess landslide hazards [11-15]. It is difficult to apply this type of reasoning in this area because only three landslides were inventoried. Therefore, the analysis should be extended to similar environments with an exhaustive inventory in order to obtain the intensity, statistical laws [77-79], and return periods of events, thereby improving results.

3. The slope stability models used are based on limit equilibrium hypotheses, which consider water in stasic and not dynamically. The use of more complex models (e.g., a model using finite difference equations like FLAC 2D/3D) would allow for taking this parameter into account, but would also require more input data. Generalization and spatialization would be complex to implement. The advantage of the ALICE ${ }^{\circledR}$ approach is to be able to model/map the potential failure areas relatively quickly without having too many data to manage while taking into account triggering factors (i.e., Ground Water Level or Peak Ground acceleration, if necessary). Moreover, the difference in terms of results (i.e., Factor of Safety) will not be significant. Indeed, several tests, including those recently performed by $[80,81]$, show a small difference in terms of results between the two approaches.

4. Little information about the relation between the groundwater table (GWL) and precipitations was available. Nevertheless, near-field studies have shown that the cumulative rainfall in the humid season was the main triggering factor and high GWL induced landslides [34-37,43]. Therefore, the GWL was introduced empirically with the hypothesis of a low GWL or a high GWL, corresponding to field observations. This step requires knowing the GWL role applied on the internal strengths and on the ground destabilization. For future studies, two axes of research about triggering conditions by precipitation could be envisaged with a procedure in two steps: (1) the pose of piezometers and rain gauge to identify on long chronicles the relation GWL; (2) once representative chronicles are acquired, it can be possible to make prospective analyses based on different climatic change scenarios elaborated by the GIEC consortium.

5. The run-out models show spatially the maximum area covered by landslide run-out following local parametrization. Results do not take into account the volumes, velocities, and intensities of the materials involved. This analysis cannot be applied as part of impact research on infrastructures. Thus, it is essential to pay close attention to the results, which require more complementary information for impact studies.

6. The planning scenarios used to assess the anthropogenic role on ground destabilization are simplistic but have the advantage of showing the possible consequences on slope stability. It is possible to question the consequences of the slope reshaping in the context of deep landslides (Figure 8). In fact, re-profiling slopes can be disastrous and may even become a triggering factor [82]. It is possible to multiply tests in the future for similar environments.

7. Lastly, anthropogenic factors are rarely taken into account in slope stability analysis and mapping; as $[10,11,15]$ point out, it is necessary to do so by answering the seven questions in Table 4 . This 
summarizes the questions that can be asked before or during studies relative to slope stability. Table 4 shows that three questions were taken into account in this study. Thus, it might be possible to improve the study-for instance, by considering in our approach the land use change, as in [82-86].

Table 4. The seven questions to ask about slope stability in relation to human activities before development.

\begin{tabular}{ll}
\hline $\begin{array}{l}\text { Questions to Consider about Slope Stability in } \\
\text { Relation with Human Activities for Future } \\
\text { Development }\end{array}$ & $\begin{array}{l}\text { Answers from this Study and Possible } \\
\text { Improvements }\end{array}$ \\
\hline Did the slope modifications affect its stability? & Considered \\
\hline $\begin{array}{ll}\text { Do the changes affect the groundwater circulation? } \\
\text { Do the changes affect the surface water amount and }\end{array}$ & $\begin{array}{l}\text { More or less considered, can be improved by use of } \\
\text { more complex models }\end{array}$ \\
$\begin{array}{ll}\text { flow path? } \\
\begin{array}{l}\text { Do the present or future land use changes and their } \\
\text { potential degradation modify any process affecting } \\
\text { slope stability? }\end{array}\end{array}$ & $\begin{array}{l}\text { Not considered, should be considered in the future by } \\
\text { integration of climatic change and elaboration of } \\
\text { scenarios in concertation with municipality }\end{array}$ \\
\hline $\begin{array}{l}\text { Are the artificial structures taking into account the } \\
\text { full environment of the slope? }\end{array}$ & $\begin{array}{l}\text { Not considered because the area to develop is } \\
\text { in cropland }\end{array}$ \\
\hline $\begin{array}{l}\text { Do the works or traffic create explosions or vibrations } \\
\text { that can affect stability? }\end{array}$ & $\begin{array}{l}\text { Not considered but can be considered because } \\
\text { national road RN1 is located near the area }\end{array}$ \\
\hline $\begin{array}{l}\text { How will the ageing of infrastructure and works } \\
\text { affect future slope stability? }\end{array}$ & $\begin{array}{l}\text { Not considered because the area to develop is } \\
\text { in cropland }\end{array}$ \\
\hline
\end{tabular}

\subsection{Recommendations/Indications}

Answering the questions of Table 4 will allow us to modify the current susceptibility map by taking into account new information obtained during the study. Based on the expert landslide susceptibility map, the spatial models, and the information obtained from cross section model analysis, we have developed two new advanced susceptibility map based (1) on Scenario 1 and (2) Scenarios 2 \& 3 with some indications for future development (Table 5 and Figure 14). The rules are inspired by the Planning and Natural Hazards Guidelines published by the Swiss Environmental Federal Office [87]. This type of approach allows us to be flexible in terms of development and offer the possibility of deliberating on new developments and the need for additional geotechnical studies, drainage, or other action in targeted locations to reduce the associated risk.

Figure 14 illustrates the possible changes in terms of rules by taking into account models, expert reasoning, and different scenarios. The susceptibility classes can be modified and the associated rules become more or less binding depending on the scenario. In the case of Figure 14B, for areas close to watercourses the rules are more restrictive (from null to moderate class). For the case of Figure 14C, the areas that could be excavated show a shift from high class to low class, as indicated by the scenario elaborated with the cross section (Figure 9). 
Table 5. Indications for developed and future developed areas following the new susceptibility classes.

\begin{tabular}{|c|c|c|c|c|}
\hline $\begin{array}{l}\text { Factor of } \\
\text { Safety } \\
\text { Computed }\end{array}$ & $\begin{array}{l}\text { Run-Out } \\
\text { Computed }\end{array}$ & $\begin{array}{c}\text { Class of } \\
\text { Susceptibility }\end{array}$ & Rules for Development & Rules in Case of Existing Development \\
\hline $\mathrm{FoS} \leq 1$ & Yes & High & No new planning and development & $\begin{array}{l}\text { Prohibition of extension } \\
\text { Regular monitoring and observations of } \\
\text { buildings and infrastructures } \\
\text { Mandatory implementation of protective } \\
\text { measures } \\
\text { Eviction of people if necessary (after careful } \\
\text { monitoring and observations) } \\
\text { Regular information to people is indispensable }\end{array}$ \\
\hline $1<\mathrm{FoS} \leq 1.2$ & No & Moderate & $\begin{array}{l}\text { Discussion and cost/benefit studies are } \\
\text { required to choose alternative solution. } \\
\text { Development possible under conditions } \\
\text { and obtaining new information (e.g., after } \\
\text { geotechnical studies, drainage, slope } \\
\text { reshaping, etc.) } \\
\text { Necessary requirements with consideration } \\
\text { of protective measures. } \\
\text { Sensible buildings and infrastructures are } \\
\text { forbidden in this area. }\end{array}$ & $\begin{array}{l}\text { Extension authorized under conditions if no } \\
\text { other solution is possible } \\
\text { Protective measures must be discussed } \\
\text { Technical measures for sensible buildings or } \\
\text { infrastructures must be discussed } \\
\text { Regular information updates to the people } \\
\text { involved are indispensable }\end{array}$ \\
\hline $\begin{array}{c}1.2<\text { FoS } \leq \\
1.5\end{array}$ & No & Low & $\begin{array}{l}\text { Sensible buildings and infrastructure are } \\
\text { not welcome in this area; possibility to } \\
\text { develop this type of infrastructure after } \\
\text { cost/benefit study. } \\
\text { New development with recommendations } \\
\text { after cost/benefit study. }\end{array}$ & $\begin{array}{l}\text { Technical measures for sensible buildings or } \\
\text { infrastructure must be discussed } \\
\text { Punctual information to people is possible }\end{array}$ \\
\hline FoS $>1.5$ & No & Null & No requirements necessary & No requirements necessary \\
\hline
\end{tabular}
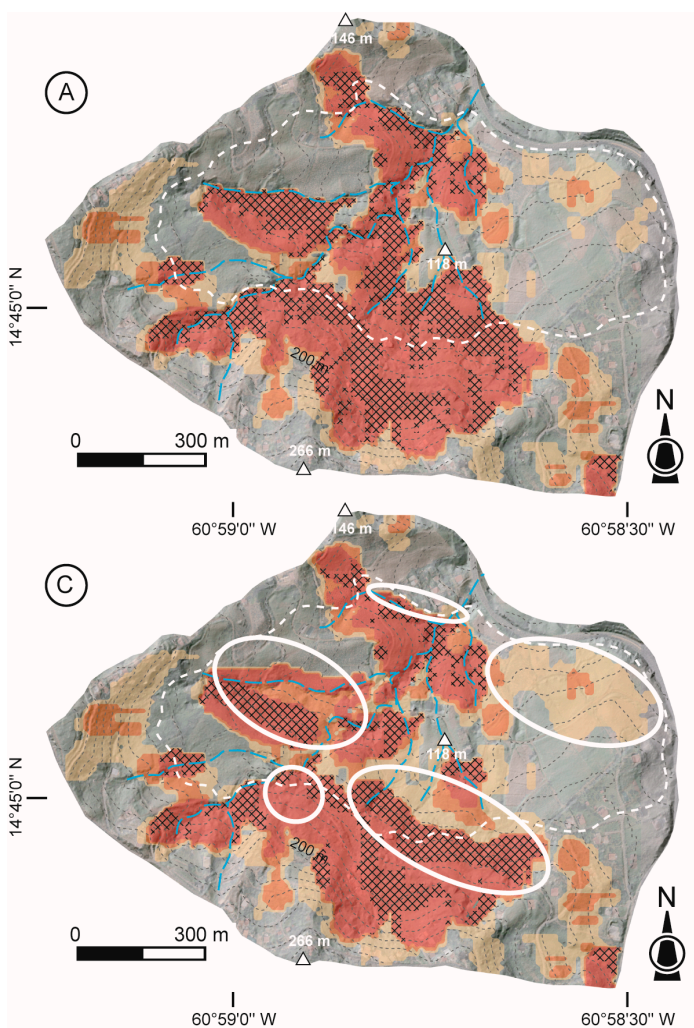
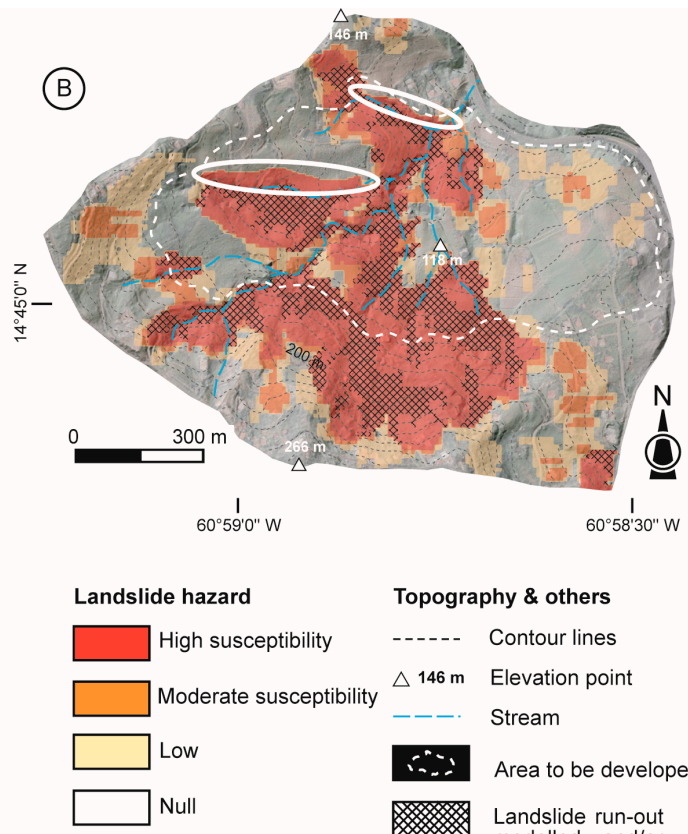

Topography \& others

-...- Contour lines

$\triangle 146 \mathrm{~m}$ Elevation point

Area to be developed Landslide run-out
modelled and/or reinterpreted

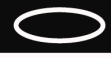

Area with changes about landslide susceptibility class between the different scenarii

Figure 14. (A) Landslide advanced susceptibility map produced by models (not taking into account expert reasoning in addition); (B) landslide advanced susceptibility map produced by models and expert reasoning for Scenario 1 (rising of GWL); (C) landslide advanced susceptibility map produced by models and expert reasoning for Scenarios 2 \& 3 (rising of GWL and anthropic works) (coordinates are expressed in Lat/Long; projection WGS84 UTM 20N-EPSG 32620). 


\section{Conclusions}

The study stresses the way to improve locally, in a complex volcanic environment, landslide susceptibility maps for areas subject to discussion about future development. Indeed, landslide susceptibility/hazard map produced by the official French method (Plans de Prévention des Risques) offer great flexibility to practitioners for the classes identified as moderate. The consequences are that often one must answer multiple questions to know if it is possible to develop the identified area without hazard and thus protect the population and property.

In response to a request from the municipality of 'La Trinité', a scenario approach was retained. It is based on transdisciplinary skills that have made it possible to use new data, such as data from the TDEM, a 3D model, or susceptibility spatial modeling for different types of landslides with different depth. The results show that certain locations are subject to discussion and could be developed without ambiguity, while for other locations this is probably not possible. In this sense, an initial response can be given to decision makers in the form of maps based on different scenarios and associated with specific rules.

Nevertheless, some improvements could be gained by: (1) integration of intensity of landslides; (2) improvement of the hydrogeology knowledge of the area by monitoring a representative location; (3) research on the relationships between precipitation and Ground Water Level known as the main triggering factors for the observed landslides in this part of the island; and (4) integration of global change including land use and climatic changes that could play a non-negligible role in instabilities in the future [88-90] (e.g., long-term precipitation inducing prolonged exposure of the regolith, an increase of the weathering mantle, and a decrease in the internal strength of materials).

However, even without considering these possible improvements, this document could be the basis of a possible re-evaluation of the landslide expert susceptibility map for the municipality of La Trinité, after validation by end users and practitioners. Finally, the approach could be used for another municipality in the French West Indies, especially in an area benefiting from TDEM data, which allow for obtaining precious information about subsoil structure and different materials.

Acknowledgments: The research was supported by the DEAL of Martinique and French Geological Survey (BRGM) contract AP16MAR008. We acknowledge the useful comments and suggestions from the two anonymous referees who helped us to enhance the manuscript. We also acknowledge our colleagues from the BRGM, Gilles Grandjean and Bastien Colas, for the constructive discussion about the approach.

Author Contributions: Yannick Thiery and Aude Nachbaur conceived and designed the study experiments; Frederic Lacquement, Maeva Lombard, Aude Nachbaur, and Yannick Thiery contributed to the field survey; Frederic Lacquement conceived the regolith map; P.-A. Reninger performed the experiments with TDEM data; A. Raingeard and Pierre-Alexandre Reninger conceived the 3D geological model; Yannick Thiery designed and performed the different landslide susceptibility models; Yannick Thiery, with the help of Frederic Lacquement, Pierre-Alexandre Reninger, and Anne Raingeard, wrote the paper.

Conflicts of Interest: The authors declare no conflict of interest. The founding sponsors had no role in the design of the study; in the collection, analyses, or interpretation of data; in the writing of the manuscript, and in the decision to publish the results.

\section{References}

1. ACS-AEC, 2017. Available online: http://www.acs-aec.org/index.php?q=disaster-risk-reduction/naturalhazards-in-the-caribbean-too-costly-to-ignore (accessed on 18 November 2017).

2. CHARIM, 2017. Available online: http:/ / www.charim.net (accessed on 18 November 2017).

3. Van Westen, C.J.; National Scale Landslide Susceptibility Assessment for Grenada. Caribbean Handbook on Risk Information Management, World Bank GFDRR, ACP-EU Natural Disaster Risk Reduction. 2016. Program. Available online: http: / / www.charim.net (accessed on 18 November 2017).

4. Van Westen, C.J.; National Scale Landslide Susceptibility Assessment for Dominica. Caribbean Handbook on Risk Information Management, World Bank GFDRR, ACP-EU Natural Disaster Risk Reduction. 2016. Program. Available online: http:/ / www.charim.net (accessed on 18 November 2017). 
5. Van Westen, C.J.; National Scale Landslide Susceptibility Assessment for Saint Vincent and the Grenadines. Caribbean Handbook on Risk Information Management, World Bank GFDRR, ACP-EU Natural Disaster Risk Reduction. 2016. Program. Available online: http:/ / www.charim.net (accessed on 18 November 2017).

6. Van Westen, C.J.; National Scale Landslide Susceptibility Assessment for Saint Lucia. Caribbean Handbook on Risk Information Management, World Bank GFDRR, ACP-EU Natural Disaster Risk Reduction. 2016. Program. Available online: http: / / www.charim.net (accessed on 18 November 2017).

7. Van Westen, C.J.; National Scale Landslide Susceptibility Assessment for Belize. Caribbean Handbook on Risk Information Management, World Bank GFDRR, ACP-EU Natural Disaster Risk Reduction. 2016. Program. Available online: http:/ / www.charim.net (accessed on 18 November 2017).

8. Momtpelat, J.M. Unités Cartographiques et Évaluation de L'aléa Mouvements de Terrain en Guadeloupe (Antilles Françaises). Ph.D. Thesis, Institut de Physique du Globe de Paris, Paris, France, 1994.

9. Durville, J.-L.; Rivière, D. Les Risques de Mouvements de Terrain sur le Site de Morne Callebase à Fort de France (Martinique). Available online: http:/ / cgedd.documentation.developpement-durable.gouv.fr/ documents / cgedd/008932-01_rapport.pdf (accessed on 18 November 2017).

10. Jaboyedoff, M.; Michoud, C.; Derron, M.; Voumard, J.; Leibundgut, G.; Sudmeier-Rieux, K.; Nadim, F.; Leroi, E. Human Induced landslides: Toward the analysis of anthropogenic changes of the slope environment. In Proceedings of the 12th International Symposium on Landslides and Engineered Slopes. Experience, Theory and Practice, Napoli, Italy, 12-19 June 2016; Aversa, S., Cascini, L., Picarelli, L., Scavia, C., Eds.; CRC Press: Boca Raton, FL, USA, 2016; pp. 217-231.

11. Fell, R.; Corominas, J.; Bonnard, C.; Cascini, L.; Leroi, E.; Savage, W.Z. Guidelines for landslide susceptibility, hazard and risk zoning for land-use planning. Eng. Geol. 2008, 102, 85-98. [CrossRef]

12. Leroi, E. Global rockfalls risk management process in 'La Désirade' Island (French West Indies). Landslides 2005, 2, 358-365. [CrossRef]

13. Corominas, J.; van Westen, C.; Frattini, P.; Cascini, L.; Malet, J.-P.; Fotopoulou, S.; Catani, F.; Van Den Eechaut, L.; Mavrouli, O.; Agliardi, F.; et al. Recommendations for the quantitative analysis of landslide risk. Bull. Eng. Geol. Environ. 2014, 73, 209-263. [CrossRef]

14. Terzaghi, K. Mechanism of Landslides. In Application of Geology to Engineering Practice; Geological Society of America: Boulder, CO, USA, 1950; pp. 83-123.

15. Van Westen, C.J.; Van Asch, T.W.J.; Soeters, R. Landslide hazard and risk zonation-Why is it still so difficult? Bull. Eng. Geol. Environ. 2006, 65, 167-184. [CrossRef]

16. Cascini, L. Applicability of landslide susceptibility and hazard zoning at different scales. Eng. Geol. 2008, 102, 164-177. [CrossRef]

17. Malet, J.-P.; Maquaire, O.; Calais, E. Le GPS en géomorphologie dynamique. Application à la surveillance de mouvements de terrain (super-Sauze, Alpes du Sud, France)/GPS in geomorphological studies. Application to the survey of landslides (super-Sauze, South France). Géomorphologie 2002, 8, 165-179. [CrossRef]

18. Van Westen, C.J. Geo-information tools for landslide risk assessment: An overview of recent developments. Landslides: Evaluation and Stabilization-Glissement de Terrain: Evaluation et Stabilisation. In Proceedings of the 9th International Symposium on Landslides, Rio de Janeiro, Brazil, 28 June-2 July 2004; pp. 39-56.

19. Crozier, M.J. Landslide geomorphology: An argument for recognition, with examples from New Zealand. Geomorphology 2010, 120, 3-15. [CrossRef]

20. Jongmans, D.; Garambois, S. Geophysical investigation of landslides: A review. Bull. Soc. Géol. Fr. 2007, 178, 101-112. [CrossRef]

21. Travelletti, J.; Malet, J.-P. Characterization of the 3D geometry of flow-like landslides: A methodology based on the integration of heterogeneous multi-source data. Eng. Geol. 2012, 128, 30-48. [CrossRef]

22. Fressard, M.; Maquaire, O.; Thiery, Y.; Davidson, D.; Lissak, C. Multi-method characterisation of an active landslide: Case study in the Pays d'Auge plateau (Normandy, France). Geomorphology 2016, 270, $22-39$. [CrossRef]

23. Grandjean, G.; Pennetier, C.; Bitri, A.; Meric, O.; Malet, J.-P. Caractérisation de la structure interne et de l'état hydrique de glissements argilo-marneux par tomographie géophysique: L'exemple du glissement-coulée de super-Sauze (Alpes du Sud, France). C. R. Geosci. 2006, 338, 587-595. [CrossRef]

24. Grandjean, G.; Malet, J.-P.; Bitri, A.; Méric, O. Geophysical data fusion by fuzzy logic for imaging the mechanical behaviour of mudslides. Bull. Soc. Géol. Fr. 2007, 178, 127-136. [CrossRef] 
25. Naudet, V.; Lazzari, M.; Perrone, A.; Loperte, A.; Piscitelli, S.; Lapenna, V. Integrated geophysical and geomorphological approach to investigate the snowmelt-triggered landslide of Bosco piccolo village (Basilicata, southern Italy). Eng. Geol. 2008, 98, 156-167. [CrossRef]

26. Chambers, J.E.; Wilkinson, P.B.; Kuras, O.; Ford, J.R.; Gunn, D.A.; Meldrum, P.I.; Pennington, C.V.L.; Weller, A.L.; Hobbs, P.R.N.; Ogilvy, R.D. Three-dimensional geophysical anatomy of an active landslide in Lias groupmudrocks, Cleveland Basin, UK. Geomorphology 2011, 125, 472-484. [CrossRef]

27. Palis, E.; Lebourg, T.; Tric, E.; Malet, J.-P.; Vida, M. Long-term monitoring of a large deep-seated landslide (La Clapiere, South-East French Alps): Initial study. Landslides 2016, 14, 155-170. [CrossRef]

28. Baroň, I.; Supper, R.; Winkler, E.; Motschka, K.; Ahl, A.; Čarman, M.; Kumelj, Š. Airborne geophysical survey of the catastrophic landslide at Stože, Log pod Mangrtom, as a test of an innovative approach for landslide mapping in steep alpine terrains. Nat. Hazards Earth Syst. Sci. 2013, 13, 2543-2550. [CrossRef]

29. Siemon, B.; Christiansen, A.V.; Auken, E. A review of helicopter-borne electromagnetic methods for groundwater exploration. Near Surf. Geophys. 2009, 7, 629-646. [CrossRef]

30. Schamper, C.; Pedersen, J.B.; Auken, E.; Christiansen, A.V.; Vittecoq, B.; Deparis, J.; Jaouen, T.; Lacquement, F.; Nehlig, P.; Perrin, J.; et al. Airborne transient EM methods and their applications for coastal groundwater investigations. In Groundwater in the Coastal Zones of Asia-Pacific; Wetzelhuetter, C., Ed.; Springer Science: Berlin, Germany, 2013.

31. Supper, R.; Baroň, I.; Ottowitz, D.; Motschka, K.; Gruber, S.; Winkler, E.; Jochum, B.; Römer, A. Airborne geophysical mapping as an innovative methodology for landslide investigation: Evaluation of results from the Gschliefgraben landslide, Austria. Nat. Hazards Earth Syst. Sci. 2013, 1, 2281-2318. [CrossRef]

32. Vittecoq, B.; Deparis, J.; Violette, S.; Jaouën, T.; Lacquement, F. Influence of successive phases of volcanic construction and erosion on Mayotte Island's hydrogeological functioning as determined from a helicopter-borne resistivity survey correlated with borehole geological and permeability data. J. Hydrol. 2013, 509, 519-538. [CrossRef]

33. Vittecoq, B.; Reninger, P.A.; Violette, S.; Martelet, G.; Dewandel, B.; Audru, J.C. Heterogeneity of hydrodynamic properties and groundwater circulation of a coastal andesitic volcanic aquifer controlled by tectonic induced faults and rock fracturing-Martinique island (Lesser Antilles-FWI). J. Hydrol. 2015, 529, 1041-1059. [CrossRef]

34. Thiery, Y.; Reninger, P.-A.; Nachbaur, A.; Vandromme, R. Exploitation de Levés D'électromagnétisme Héliporté Dans une Perspective de Réévaluation des Cartes d'aléa «Mouvement de Terrain» en Milieu Volcanique Tropical, Rapport Intermédiaire. Available online: http:/ /infoterre.brgm.fr/rapports/RP-65407FR.pdf (accessed on 18 November 2017).

35. Thiery, Y.; Reninger, P.-A.; Nachbaur, A. Exploitation de Levés D'électromagnétisme Héliporté Dans une Perspective de Réévaluation des Cartes D'aléa «Mouvement de Terrain» en Milieu Volcanique Tropical. Rapport Final. Available online: http:/ /infoterre.brgm.fr/rapports/RP-66605-FR.pdf (accessed on 18 November 2017).

36. Thiery, Y.; Reninger, P.-A.; Vandromme, R.; Nachbaur, A. Contribution of Heliborne Electro-Magnetic Survey for Landslide Prediction: Application to La Martinique (West Indies, France); EGU: Vienne, Austria, 2017; Volume 19, p. 13970.

37. Thiery, Y.; Reninger, P.-A.; Vandromme, R.; Nachbaur, A. Contribution of Heliborne Electro-Magnetic Survey for Landslide Recognition and Modelling: Application to La Martinique (West Indies, France). In Proceedings of the 25ème Réunion des Sciences de la Terre (RST 2016), Caen, France, 24-28 October 2016; Available online: https:/ /rst2016-caen.sciencesconf.org (accessed on 18 November 2017).

38. Germa, A.; Quidelleur, X.; Labanieh, S.; Chauvel, C.; Lahitte, P. The volcanic evolution of Martinique Island: Insights from K-Ar dating into Antilles arc migration since the Oligocene. J. Volcanol. Geotherm. Res. 2008, 208, 122-135. [CrossRef]

39. Barras, A.-V.; Vanoudheusden, L.; Le Moigne, B.; Bayle, E. Intempéries du 5 mai 2009 en Martinique et Mouvements de Terrain Associés: Interventions en Situation de Crise, Inventaire Post-Crise et Retour D'expérience. Available online: http://infoterre.brgm.fr/rapports/RP-58851-FR.pdf (accessed on 18 November 2017).

40. Varnes, D.J. Slope movement types and processes. In Landslides: Analysis and Control; Special Report 176, Transportation Research Board; Schuster, R.L., Krizek, R.J., Eds.; National Research Council: Washington, DC, USA, 1978; pp. 11-33. 
41. Corominas, J. Debris slide. In Landslide Recognition-Identification, Movement and Causes; Dikau, R., Brunsden, D., Schrott, L., Ibsen, M.-L., Eds.; Wiley: Chichester, UK, 1996; pp. 97-102.

42. Cruden, D.M.; Varnes, D.J. Landslide Types and Processes Landslides: Investigation and Mitigation; Special Report No. 247, Transportation Research Board; Turner, A.K., Shuster, R.L., Eds.; National Research Council: Washington, DC, USA, 1996; pp. 36-75.

43. Allard, J.F. RN1 Carrefour Nord de Trinité—Glissement du Morne Figue-Trinité-Martinique, Etude Géotechnique. Available online: http://infoterre.brgm.fr/rapports/89-MTQ-082.pdf (accessed on 18 November 2017).

44. Buma, J.; van Asch, T. Slide (rotational). In Landslide Recognition-Identification, Movement and Causes; Dikau, R., Brunsden, D., Schrott, L., Ibsen, M.-L., Eds.; Wiley: Chichester, UK, 1996; pp. 43-61.

45. Mompelat, J.-M.; Audru, J.-C.; Terrier, M.; Bertil, D. Prévention du Risque Sismique aux Antilles Françaises. Geosciences 2011, 14, 68-75.

46. Westercamp, D.; Andreieff, P.; Bouysse, P.; Cottez, S.; Battistini, R. Notice Explicative de la Carte Géologique à 1: 50 000ème de la Martinique; BRGM: Orleans, France, 1989; 286p.

47. Dearman, W.R.; Shibakova, V.S. The tropical environment. In Engineering Geology of the Earth; Dearman, W.R., Sergueev, E.M., Shibakova, V.S., Eds.; Nauka Publishers: Moscow, Russia, 1989; pp. 128-141.

48. Ollier, C.-D.; Calcaterra, D.; Parise, M. Studies in weathering and slope movements-an introduction. Geomorphology 2007, 87, 101-103. [CrossRef]

49. Ollier, C.-D. Very dep weathering and related landslides. In Weathering as a Predisposing Factor to Slope Movements; Calcaterra, D., Parise, M., Eds.; Engineering Geology Special Publications: London, UK, 2010; Volume 23, pp. 5-14. [CrossRef]

50. Sørensen, K.I.; Auken, E. SkyTEM: A new high-resolution helicopter transient electromagnetic system. Explor. Geophys. 2004, 35, 191-199.

51. Spies, B.R. Depth of investigation in electromagnetic sounding methods. Geophysics 1989, 54, 872-888. [CrossRef]

52. Ward, S.H.; Hohmann, G.W. Electromagnetic theory for geophysical applications. In Electromagnetic Methods in Applied Geophysics; Nabighian, M.N., Ed.; Society of Exploration Geophysicists: Tulsa, OK, USA, 1988; Volume 1, pp. 131-311.

53. Viezzoli, A.; Christiansen, A.V.; Auken, E.; Sørensen, K. Quasi-3D modeling of airborne TEM data by spatially constrained inversion. Geophysics 2008, 73, 105-113. [CrossRef]

54. Christiansen, A.V.; Auken, E. A global measure for depth of investigation. Geophysics 2012, 77, WB171-WB177. [CrossRef]

55. Calcagno, P.; Chilès, J.P.; Courrioux, G.; Guillen, A. Geological modelling from field data and geological knowledge: Part I. Modelling method coupling 3D potential-field interpolation and geological rules. Phys. Earth Planet. Inter. 2008, 171, 147-157. [CrossRef]

56. Martelet, G.; Calcagno, P.; Gumiaux, C.; Truffert, C.; Bitri, A.; Gapais, D.; Brun, J.P. Integrated 3D geophysical and geological modelling of the Hercynian Suture Zone in the Champtoceaux area (South Brittany, France). Tectonophysics 2004, 382, 117-128. [CrossRef]

57. Glade, T.; Crozier, M.J. A review of scale dependency in landslide hazard and risk analysis. In Landslide Hazard and Risk; Glade, T., Anderson, M., Crozier, M.J., Eds.; Wiley: Chichester, UK, 2005; pp. 75-138.

58. Guzzetti, F.; Carrara, A.; Cardinali, M.; Reichenbach, P. Landslide hazard evaluation: A review of current techniques and their application in a multi-scale study, central Italy. Geomorphology 1999, 31, 181-216. [CrossRef]

59. Guzetti, F.; Reichenbach, P.; Ardizzone, F.; Cardinali, M.; Galli, M. Estimating the quality of landslide susceptibility models. Geomorphology 2006, 81, 166-184. [CrossRef]

60. Remondo, J.; Gonzàlez-Diez, A.; Dìaz de Teràn, J.R.; Cendrero, A. Landslides susceptibility models utilising spatial data analysis techniques. A case study from the lower Deba Valley, Guipùzcoa (Spain). Nat. Hazards 2003, 30, 267-279. [CrossRef]

61. Thiery, Y.; Malet, J.-P.; Sterlacchini, S.; Puissant, A.; Maquaire, O. Landslide susceptibility assessment by bivariate methods at large scales: Application to a complex mountainous environment. Geomorphology 2007, 92, 38-59. [CrossRef]

62. Brabb, E.E. Innovative approaches to landslide hazard mapping. In Proceedings of the Fourth International Symposium on Landslides, Toronto, ON, Canada, 10-15 July 1984; pp. 307-324. 
63. Soeters, R.; Van Westen, C.J. Slope instability, recognition, analysis, and zonation. In Landslides Investigation and Mitigation; Transportation Research Board, Special Report 247; Turner, A.K., Schuster, R.L., Eds.; National Research Council: Washington, DC, USA, 1996; pp. 129-177.

64. Duncan, J.-M. Soil slope stability analysis. In Landslides: Investigation and Mitigation; Transportation Research Board, Special Report 247; Turner, A-K., Schuster, R-L., Eds.; National Academy Press: Washington, DC, USA, 1996; pp. 337-371.

65. Vandromme, R.; Desramaut, N.; Garnier, C.; Bernardie, S. A Novel Approach to Integrate Effects of Vegetation Changes on Slope Stability. In Engineering Geology for Society and Territory_Volume 2; Lollino, G., Giordan, D., Crosta, G.B., Corominas, J., Azzam, R., Wasowski, J., Sciarra, N., Eds.; Springer: Cham, Switzerland, 2014; p. 47.

66. Thiery, Y.; Vandromme, R.; Maquaire, O.; Bernardie, S. Landslide susceptibility assessment by EPBM (Expert physically based model): Strategy of calibration in complex environment. In Advancing Culture of Living with Landslides, Volume 2 Advances in Landslide Science, Proceedings of the 4th World Landslide Forum, Ljubljana, Slovenia, 29 May-2 June 2017; Mikoš, M., Tiwari, B., Yin, Y., Sassa, K., Eds.; Springer: Berlin, Germany, 2017; pp. 917-926.

67. Sedan, O.; Mirgon, C.; Bes de Berc, S. Cartographie de l'aléa Mouvement de Terrain-Prise en Compte de la Propagation-Programme BORA-Technical Report. BRGM/RP-54650-FR. 2006. Available online: http:/ / infoterre.brgm.fr/rapports/RP-54650-FR.pdf (accessed on 18 November 2017).

68. Morgenstern, N.R.; Price, V. The analysis of the stability of general slip surfaces. Geotechnique 1965, 15, 79-93. [CrossRef]

69. Zhu, D.Y.; Lee, C.F.; Qian, Q.H.; Chen, G.R. A concise algorithm for computing the factor of safety using the Morgenstern-Price method. Can. Geotech. J. 2005, 42, 272-278. [CrossRef]

70. IGN; SHOM (Eds.) IGN-Litto3D ${ }^{\circledR}$ Version 1.0. Descriptif Technique. 2015. Available online: http:// professionnels.ign.fr/doc/DC_Litto3D.pdf (accessed on 18 November 2017).

71. MATE/MATL. Plan de Prévention des Risques (PPR): Risques de Mouvements de Terrain; La Documentation Française; Ministère de l'Aménagement du Territoire et de l'Environnement (MATE), Ministère de l'Equipement des Transports et du Logement (METL): Paris, France, 1999; 74p.

72. Leroi, E. Landslide hazard—Risk maps at different scales: Objectives, tools and development. In Proceedings of the ISL'96, 7th International Symposium on Landslides, Trondheim, Norway, 17-21 June 1996.

73. Audru, J.-C.; Nachbaur, A.; Colas, B.; Rinaudo, J.-D.; Le Roy, M.; Barnerias, I. Les mouvements de terrain en Martinique (Antilles françaises): Risques, aide à la décision et politique de gestion. In Proceedings of the 8éme Colloque sur Les Risques Naturels au Québec, Conférences ACFAS, Université Laval, Quebec City, QC, Canada, 20-24 May 2008.

74. NF EN 1991-1-1. Eurocode 1-Actions sur les Structures-Partie 1-1: Actions Générales-Poids Volumiques, Poids Propres, Charges D'exploitation des Bâtiments. 2003. Available online: http:/ / freeit.free.fr/eurocodes / EC1\%201.1\%20FA102763.PDF (accessed on 18 November 2017).

75. Reninger, P.A.; Martelet, G.; Perrin, J. Frame effective tilt correction for HEM data acquired over rugged terrain. In Proceedings of the First European Airborne Electromagnetics Conference, Turin, Italy, 6-10 September 2015.

76. Reninger, P.-A.; Martelet, G.; Deparis, J.; Perrin, J.; Chen, Y. Singular value decomposition as a denoising tool for airborne time domain electromagnetic data. J. Appl. Geophys. 2001, 75, 264-276. [CrossRef]

77. Guzzetti, F.; Reichenbach, P.; Ardizzone, F.; Cardinalli, M.; Galli, M. Estimating the quality of landslide susceptibility models. Geomorphology 2006, 81, 166-184. [CrossRef]

78. Godt, J.W.; Baum, R.L.; Chleborad, A.F. Rainfall characteristics for shallow landsliding in Seattle, Washington, USA. Earth Surf. Process. Landf. 2006, 31, 97-110. [CrossRef]

79. Guzzetti, F.; Peruccacci, S.; Rossi, M.; Stark, C.P. The rainfall intensity-duration control of shallow landslides and debris flows: An update. Landslides 2008, 5, 3-17. [CrossRef]

80. Matthews, C.; Farook, Z.; Helm, P.-R. Slope stability analysis-Limit equilibrium or the finite element method? Ground Eng. 2014, 48, 22-28.

81. Liu, S-Y.; Shao, L-T.; Li, H-J. Slope stability analysis using the limit equilibrium method and two finite element methods. Comput. Geotech. 2015, 63, 291-298. [CrossRef] 
82. Jaboyedoff, M.; Oppikofer, T.; Locat, A.; Locat, J.; Turmel, D.; Robitaille, D.; Demers, D.; Locat, P. Use of ground-based Lidar for the analysis of retrogressive land-slides in sensitive clay and of rotational landslides in river banks. Can. Geotech. J. 2009, 46, 1-12. [CrossRef]

83. Reichenbach, P.; Busca, C.; Mondini, A.C.; Rossi, M. The Influence of Land Use Change on Landslide Susceptibility Zonation: The Briga Catchment Test Site (Messina, Italy). Environ. Manag. 2014, 54, 1372-1384. [CrossRef] [PubMed]

84. Van Beek, L.P.H.; Van Asch, T. Regional assessment of the effects of land-use change on landslide hazard by means of physically based modelling. Nat. Hazards 2004, 31, 289-304. [CrossRef]

85. Meusburger, K.; Alewell, C. Impacts of anthropogenic and environmental factors on the occurrence of shallow landslides in an alpine catchment (Urseren Valley, Switzerland). Nat. Hazards Earth Syst. Sci. 2008, 8, 509-520. [CrossRef]

86. Giordan, D.; Cignetti, M.; Baldo, M.; Godone, D. Relationship between man-made environment and slope stability: The case of 2014 rainfall events in the terraced landscape of the Liguria region (Northwestern Italy). Geomat. Nat. Hazards Risks 2017, 8, 1833-1852. [CrossRef]

87. Swiss Environmental Federal Office. Recommendation-Aménagement du Territoire et Dangers Naturels. Office Fédéral du Développement Territorial, Office Fédéral des Eaux et de la Géologie, Office Fédéral de L'environnement, des Forêts et du Paysage, Eds.; 2005; 50p. Available online: https:/ / www.vd.ch/fileadmin/ user_upload/themes/territoire/dangers_naturels/fichiers_pdf/recommandation_AT-DN.pdf.pdf (accessed on 18 November 2017).

88. Donnelly, L.J. Landslides associated with the Soufrière Hills Volcano, Montserrat, West Indies. In Landslides and Climate Change-Challenge and Solutions; Mc Innes, R., Jakeways, J., Fairbanks, H., Mathie, E., Eds.; Taylor and Francis Group: London, UK, 2007; pp. 311-320.

89. Crozier, M.J. Deciphering the effect of climate change on landslide activity: A review. Geomorphology 2010, 124, 260-267. [CrossRef]

90. Gariano, S.L.; Guzzetti, F. Landslides in a changing climate. Earth-Sci. Rev. 2016, 162, 227-252. [CrossRef]

(C) 2017 by the authors. Licensee MDPI, Basel, Switzerland. This article is an open access article distributed under the terms and conditions of the Creative Commons Attribution (CC BY) license (http:/ / creativecommons.org/licenses/by/4.0/). 